\title{
A Anatel como ferramenta republicana na internalização de normas internacionais
}

The Anatel as a Republican Tool for the Internalization of International Rules

\section{Resumo}

O surgimento das agências reguladoras no Brasil - e a atividade regulatória desempenhada por elas - colaborou com um movimento histórico de deslocamento do centro de legitimação das políticas públicas setoriais do Poder Legislativo para o Poder Executivo. Isso foi acompanhado por uma maior abertura democrática das agências em seu processo de produção normativa. Entretanto, após o movimento de reforma do Estado dos anos 1990, uma parte das políticas parece ainda não ter encontrado no Poder Executivo meio suficiente de legitimação: as normas e pseudonormas setoriais produzidas no âmbito internacional. Afirma-se isso com base na filosofia republicana, que se afere estar na base das instituições do Estado moderno, e mediante a análise da regulação dos serviços de telecomunicações, a forma como esse setor regulamenta o seu relacionamento normativo com o ambiente internacional e como ele, de fato, ingere e deglute as normas administrativas internacionais. Como resultado, observa-se que o setor de telecomunicações dispõe de instituições republicanas de participação social em seus processos normativos que se aplicam, de maneira geral, à transposição de normas internacionais para o direito interno. No entanto, pode ser verificado que, em certos casos, a abordagem dessas normas pelo setor ainda retém incoerências, além de carecer de etapas que alinhem o processo de internalização à ideia neorrepublicana de democracia contestatória, deliberativa ou participativa.

Palavras-chave: republicanismo; regulação; telecomunicações; direito internacional; Brasil.

\section{Abstract}

The design and the actual implementation of regulatory authorities in Brazil played an important role in the historical tendency of displacing the legitimation center of public policies from the legislative to the executive branch, as the regulatory

\footnotetext{
"Bacharel e Mestre em Direito pela Universidade de Brasília. Procurador Federal. Diretor do Departamento de Banda Larga do Ministério das Comunicações do Brasil. Contato: coimbradeoliveira@yahoo.com.br.
} 
authorities' law-making process became way more transparent and participative. Nevertheless, after the state reform movement that took place in Brazil during the 1990s, certain policies have not found their way to sufficient legitimation through the executive branch: international rules and soft law. This statement is supported by republican philosophy, which underlies modern state's institutions, and by the concrete analysis of regulations in telecommunications services, as well as by observing the way the regulator deals with pertinent international administrative rules. This article concludes that this regulated area holds republican institutions that ensure universal political participation in the decision-making process, including the penetration of international law in the national environment. Nonetheless, in many cases these international standards and rules present themselves with an incoherent status and their internalizing processes often lack necessary steps in order to be in touch with a neo-republican conception of democracy.

Keywords: Republicanism; regulation; telecommunications; international law; Brazil.

\section{Introdução: as bases republicanas do Estado Moderno}

As instituições brasileiras não são exclusivamente fruto da criatividade do Poder Constituinte originário ou do legislador nacional. Em verdade, elas têm como referência uma história cujo início é difícil precisar. Ele pode ser apontado na Proclamação da República, na Independência do Brasil, no

ambiente revolucionário americano e francês do século XVIII, na commonweatlh inglesa do século XVII, na Florença do século XV, na Roma antiga, enfim, qualquer ponto de partida é arbitrário. $\mathrm{O}$ fato é que todos esses eventos têm em comum uma base filosófica ou ideológica: o republicanismo.

Republicanismo pode ser definido como um paradigma de ideias e concepções sobre o homem, a política, o Estado e a coisa pública, em sentido próximo ao tido por John Greville Agard Pocock. Trata-se, portanto, de um conjunto ideológico que se mantém mais ou menos coerente e perene ao longo dos séculos, tendo aportado em diversas áreas do conhecimento, sobretudo na política e no direito. No linguajar kuhniano, seria algo como 
um paradigma científico; em uma visão braudeliana, uma estrutura de longa duração. ${ }^{1}$

A ideia de liberdade republicana, que permeia as instituições do Estado moderno, atribui importância à participação política. Liberdade, para o republicanismo, pode ser definida como ausência de dominação. Existe dominação quando existe interferência arbitrária. Portanto, a liberdade republicana consiste na ausência de interferência arbitrária. Para preservá-la, faz-se fundamental a participação política nos negócios públicos. Somente dessa forma se pode garantir, em concreto, a inexistência de interferência arbitrária na vida dos cidadãos. Quanto maior e mais legítima a participação, maior é a liberdade.

Democracia participativa é a roupagem filosófico-institucional contemporânea dos ideais republicanos. ${ }^{2} \mathrm{O}$ republicanismo contemporâneo (ou neorrepublicanismo) admite a impossibilidade da democracia direta recepciona, portanto, a ideia de democracia representativa -, porém tenta resgatar a participação direta dos cidadãos que sempre caracterizou os governos republicanos. O contexto, todavia, é diferente. Por um lado, o Estado moderno conta com uma burocracia profissionalizada que, em si, naturalmente afasta o cidadão comum do governo. O burocrata profissional, por outro lado, não pode exercer o poder da mesma forma como se esperava que isso fosse feito nas repúblicas pré-modernas de constituição mista. Nelas, cada classe institucionalmente representada defendia os seus interesses em procedimentos coletivos de composição de interesses. O burocrata moderno age em nome de toda a sociedade, sem poder privilegiar indevidamente uma classe, um estrato ou um grupo social em detrimento de outro.

${ }^{1}$ Uma estrutura de longa duração é, para Fernand Braudel, no contexto historiográfico da Escola dos Annales, tudo, na história, que não pode ser observado pela pessoa comum, a ponto de ser quase imóvel no tempo. Para um detalhamento da linguagem dos Annales, vide: BURKE (2003).

${ }^{2} \mathrm{~A}$ relação entre republicanismo e democracia modificou-se ao longo dos séculos. Os autores clássicos sempre demonstraram desconfiança na capacidade de o povo exercer o autogoverno por si mesmo e, por conseguinte, repúblicas aristocráticas tiveram um espaço significativo na tradição intelectual republicana. Maquiavel, Montesquieu e, sobretudo, os federalistas foram marcos de evolução e de convergência entre a ideia de república e de democracia. 
Na visão de John Schwarzmantel (2006), os republicanos do século XVIII viam com reservas a ampliação da participação popular, por receio de uma tirania do povo, um despotismo. É interessante destacar que, no surgimento do Estado moderno, a partir do século XIX, eventual democracia almejada pelas repúblicas não era propriamente neorrepublicana. $\mathrm{O}$ liberalismo de então via a democracia como o cumprimento de procedimentos e como o respeito a instituições formais, tais quais as eleições periódicas. Ainda tinha, por conseguinte, um caráter marcadamente aristocrático, que se manteve forte no pensamento político e constitucional até o século passado. Rejeitava-se a extensão dos direitos de cidadão a literalmente toda a população, sem distinções com base em sexo, etnia ou riqueza.

A partir do século XIX, esses direitos começaram a se ampliar e a república que era formalmente democrática passou a esforçar-se para sê-lo materialmente. Esse movimento transitou pela socialdemocracia e foi acompanhado por uma progressiva organização de setores da sociedade civil (sindicatos, organizações não governamentais, associações etc.), que buscava alguma participação efetiva no governo. (PEREIRA 2009, 185-8)

Hoje, a democracia é um atributo intensamente perseguido, ainda que apenas nominalmente às vezes, pelos regimes que se dizem republicanos. De acordo com Pettit (1997), não é necessário que uma democracia preveja a necessidade de consenso para que uma norma seja considerada legítima ou não arbitrária, mas é imprescindível haver meios pelos quais o cidadão possa contestar, em diversos momentos, as decisões das autoridades.

Cass Sunstein (1987-1988) opõe duas concepções sobre a política que, historicamente, sempre estiveram em disputa: a concepção pluralista e a concepção do republicanismo cívico. À luz da primeira, a política é vista como a briga entre grupos de interesse que, para fazerem valer seus desejos, pressionam os agentes do Estado e, a partir disso, gera-se um equilíbrio. Essa visão nitidamente utilitarista da política trabalha com a ideia de agregação de preferências que têm natureza pré-política. A política, assim, padeceria do mal de atender aos grupos mais fortes, cujos interesses chegariam ao conhecimento do Estado.

Como alternativa à perspectiva pluralista, Sunstein aponta a concepção republicana da política, que se fundamenta em quatro compromissos fundamentais. $\mathrm{O}$ primeiro consiste na deliberação, entendida como uma Revista de Direito, Estado e Telecomunicações, v. 4, n. 1, p. 83-136 (2012) 
postura crítica frente às vontades e aos atos postos, que devem ser submetidas a debate público. A deliberação pressupõe que as preferências não são exógenas à política e são passíveis de debate pelos cidadãos, na busca de uma resultante que seja boa para a comunidade em geral - esse, o concreto exercício da virtude cívica. O segundo compromisso político republicano trata-se de conferir igual acesso para todos aos processos deliberativos. O terceiro é o compromisso com o universalismo, ou seja, com o objetivo de sintetizar as diferentes concepções do bem comum em diálogos e em acordos pragmática e mutuamente satisfatórios, que não sejam formados pela barganha das partes. O último compromisso destacado por Sunstein é a ideia de cidadania e participação, concretizada na possibilidade real e efetiva de se exercer controle social sobre as práticas institucionais, não apenas com o objetivo de evitar o surgimento de facções ou o uso indevido de cargos por representantes, mas como manilha de preservação da própria liberdade. ${ }^{3}$

${ }^{3}$ Em outro texto, o autor identifica essas características presentes já nos debates e nas ideias dos Founding Fathers: "Os formuladores da Constituição beberam consideravelmente do republicanismo clássico, o que se refletiu especialmente na valorização da deliberação política, da virtude política, do debate político e da cidadania. Madison e Hamilton, em particular, enfatizaram a necessidade de deliberação entre os diferentemente situados. As instituições básicas da representação, dos freios e contrapesos e do federalismo são mais bem compreendidas sobre esse pano de fundo. Até mesmo os direitos individuais salvaguardados pela Constituição - o direito a ser julgado por um júri e os direitos de associação e de petição, por exemplo - devem-se, em grande parte, à tradição republicana. Os formuladores da Constituição dificilmente eram pluralistas no sentido de grupos de interesse, economistas do bem-estar social ou crentes em uma esfera pré-política de direitos privados. Eles eram republicanos, embora de uma nova estirpe; e também eram liberais." [Tradução livre do original: "The framers of the Constitution drew a considerable amount from classical republicanism, especially insofar as they placed a high premium on political deliberation, political virtue, political debate, and citizenship. Madison and Hamilton in particular emphasized the need for deliberation among the differently situated. The basic institutions of representation, checks and balances, and federalism are best understood against this background. Even the individual rights safeguarded by the Constitution - the right to a jury trial and the rights of assembly and petition, for example - owe a large amount to the republican tradition. The framers were hardly interest-group 
Para concretizar a democracia política republicana, em cada foro decisório, deve haver procedimentos por meio dos quais os cidadãos possam questionar e tecer considerações relevantes à matéria sendo decidida. Além disso, a democracia republicana deve ter um caráter inclusivo, ou seja, as pessoas devem ser capazes de vocalizar e de serem ouvidas. Por fim, precisa-se de um lugar ou espaço em que as pessoas sejam ouvidas.

O que importa sob essa concepção é, precisamente, que a democracia provê um ambiente para a seleção das leis que assegura que as sobreviventes são geralmente satisfatórias; na medida em que as sobreviventes tenham sido capazes de sustentar-se em face das contestações contra si elaboradas, pode-se presumir que elas correspondem aos interesses e às ideias de boa parte das pessoas. ${ }^{4}$ (PETTIT 1997, 201)

Nunca se terá uma política pública ou uma norma totalmente não dominadora, mas as instituições republicanas e a participação popular contribuem para se chegar o mais próximo possível disso, à medida que rastreiem os interesses publicamente legítimos dos cidadãos. "Não é suficiente confiar apenas em eleições periódicas como forma de expressão de preferências pelas pessoas"5 (MAYNOR 2006, 130). A verificação da ausência de dominação deve ocorrer na ponta da entrada (a formulação) e na ponta da saída (os resultados efetivamente gerados) das políticas públicas. (BELLAMY 2008)

$\mathrm{O}$ rastreamento dos interesses dos cidadãos deve ocorrer em vários momentos. Primeiro, ele deve guiar as questões a serem, de fato, escolhidas pelo Estado para serem resolvidas, o que pode ocorrer por meio da elaboração de estudos ou publicações abertas e claras para a população

pluralists, welfare economists, or believers in a prepolitical sphere of private rights. They were republicans, albeit of a novel stripe; they were liberals as well."] (SUNSTEIN 1988).

${ }^{4}$ Tradução livre do original: "For what is important under that conception is precisely that democracy provides an environment for the selection of laws which ensures that survivors are generally satisfactory; to the extent that survivors have proved capable of withstanding the contestations made against them, they may be presumed to answer to the interests and ideas of people at large."

${ }^{5}$ Tradução livre de: "It is not enough simply to rely on the people to express their preferences in periodic elections."

Revista de Direito, Estado e Telecomunicações, v. 4, n. 1, p. 83-136 (2012)

DOI: https://doi.org/10.26512/lstr.v4i1.21576 
manifestar-se. As questões levantadas pelos cidadãos devem ser, em seguida, respondidas fundamentadamente no âmbito do processo legislativo ou executivo e devem levar à elaboração inicial de políticas concretas. Essas propostas de políticas devem estar sujeitas a revisões e contestações da população; isso ocorre, frequentemente, por meio de consultas, audiências e debates públicos. Depois de formulada definitivamente a política, ela ainda deve estar sujeita a revisões periódicas. (MAYNOR 2003, 158-68)

\section{Republicanismo e agência reguladora}

Ao longo do século XX, dois movimentos administrativos orientaram a evolução do relacionamento entre Poder Legislativo e Poder Executivo no Estado de países ocidentais como Estados Unidos da América e Brasil: o agigantamento do Poder Executivo, ocupando espaços antes tidos como exclusivos, privativos ou, ao menos, primordiais do próprio Poder Legislativo, e o fenômeno da descentralização interna no próprio Poder Executivo.

Em específico, a passagem de matérias antes deliberadas pelo Legislativo para o Executivo não se deu pacificamente. Muitas discussões jurisprudenciais e doutrinárias ocorreram. ${ }^{6}$ Uma das questões levantadas é sintetizada abaixo:

Em 1789, a deliberação a respeito do estabelecimento de maior parte das políticas federais ocorria no Congresso. Duzentos anos depois, o Congresso havia transferido à burocracia federal grandes porções da sua autoridade para elaborar políticas relacionadas a muitos dos assuntos que se enquadram em sua competência estabelecida na seção 8 do artigo I. A necessidade de uma deliberação suficientemente consistente na criação de políticas públicas não diminui, independentemente de quem tem 0 poder legal para decidir. Hoje, as responsabilidades deliberativas são bastante aderentes aos departamentos e às agências - sejam ou não chamados de "independentes" -, que são ocupadas não por deputados ou senadores, mas por "diretores" e "funcionários" dos Estados Unidos. (LUNEBURG 1991, 370)

${ }^{6}$ Para um excelente relato desses debates, vide: LAENDER (2009).

${ }^{7}$ Tradução livre do original: "In 1789, deliberation over the establishment of most federal policy took place in Congress. Two hundred years later, Congress has 
Em virtude disso, nos EUA, os tribunais e o próprio Congresso passaram a exigir medidas específicas a serem seguidas pelas agências em sua produção normativa. Os procedimentos formalizaram-se significativamente, principalmente a partir da década de 1960. As agências tiveram de divulgar publicamente suas propostas para novas regras, com as devidas fundamentações e com espaço e tempo para comentários, estabelecendo-se um diálogo público com a sociedade, no qual a agência também responde aos argumentos apresentados e, até mesmo, evita contatos com interessados por fora do procedimento estabelecido. (DIVER 1981)

No Brasil, esse movimento de instituição de atribuições genéricas ao Executivo e de descentralização administrativa também pode ser verificado com a criação de mais de cento e cinquenta autarquias e fundações públicas ao longo do século XX, culminando na política de reforma do Estado da década de 1990, que instituiu, formalmente, agências reguladoras com expresso poder normativo. ${ }^{8}$ A transferência - ou a formalização da transferência - de um poder normativo para o Poder Executivo desloca, conjuntamente, o foro de debates aos quais o processo administrativo de deliberação deve estar aberto, para o fortalecimento da legitimidade das normas produzidas e, em última análise, para a garantia da liberdade das pessoas afetadas pelos seus efeitos.

Mark Seidenfield (1992) vê a consolidação histórica das agências reguladoras nos EUA como um movimento errático, que já teve três justificativas diferentes conforme o momento histórico. Logo que surgiram, eram vistas como agentes necessários para a execução das políticas

transferred away to the federal bureaucracy large portions of its authority to make policy regarding the many subjects falling within the authority of the various heads of power set forth in section 8 of article I. The need for sufficient deliberation in the creation of public policy is not diminished, no matter who has the legal power to decide. Today deliberative responsibilities attach largely to departments and agencies - whether or not formally labelled 'independent' - which are populated not by Representatives and Senators, but by 'officers' and 'employees' of the United States."

${ }^{8}$ Como esclarece Gierck Medeiros (2005), a instituição do modelo de agências reguladoras no País, ao final do século XX, não foi uma grande inovação, pois o Brasil já contava com organizações com atributos bastante similares desde o início do século.

Revista de Direito, Estado e Telecomunicações, v. 4, n. 1, p. 83-136 (2012)

DOI: https://doi.org/10.26512/lstr.v4i1.21576 
elaboradas pelo Congresso. Essa explicação, todavia, não era convincente, porque entrava em choque com o fato de que elas exerciam papel criativo diante das diretrizes cada vez mais amplas e abstratas promulgadas pelo Congresso Nacional.

A segunda justificativa, portanto, surgida após o New Deal, aceita que as agências tenham ampla liberdade para definição de políticas e mesmo dos valores a serem concretamente perseguidos em cada política, porque reconhece que os setores sujeitos a regulação dependem de entes com expertise técnica relativamente isolados do jogo político que permeia os órgãos do núcleo do Poder Executivo. ${ }^{9}$ Não tardou a ficar claro que a expertise técnica não era capaz de suprir, por si só, escolhas essencialmente políticas que as agências tinham de fazer na base de suas políticas, nem a transforma em um ente apolítico.

A partir disso, Seidenfeld aponta que, nas últimas décadas, ganhou força a visão da regulação com base em uma perspectiva pluralista da democracia. Sob essa visão, as agências funcionariam como equilibristas dos interesses privados pré-políticos que a circundam e apenas alterariam o status quo quando um desses grupos demonstrasse estar insatisfeito com a equação presente. Somente as agências teriam capacidade de atuar dessa maneira, pois são mais especializadas que o Congresso Nacional para o exercício desse mister.

Considerando todas essas justificativas como insuficientes e parciais, Seidenfeld propõe uma legitimação das agências com base no republicanismo cívico. Na medida em que as políticas e as normas de uma sociedade devem refletir algum grau de consenso político, deve-se permitir o acesso de todas as pessoas ao processo formulador. Isso não elimina a importância ou o papel dos grupos de interesse. Eles são peças fundamentais no processo deliberativo, mas a agência republicana considera todos os interesses com igualdade e não se limita a agir apenas quando incomoda, ou seja, não satisfaz apenas os interesses dos que têm poder de manifestar incômodo.

Não se pode negar que há exagero quando Seidenfeld afirma que "as agências administrativas (...) devem ser as únicas instituições capazes de

${ }^{9}$ Seidenfeld aponta que a Federal Communications Commission (FCC) surgiu nesse
contexto de justificação (SEIDENFELD 1992, 1519). Revista de Direito, Estado e Telecomunicações, v. 4, n. 1, p. 83-136 (2012) DOI: https://doi.org/10.26512/lstr.v4i1.21576 
preencher o ideal deliberativo do republicanismo cívico"10 $(1992,1541)$. O que há por trás disso, no entanto, é a constatação de que as agências desempenham, acima de um papel técnico, um papel político. Dessa forma, o republicanismo cívico tem o potencial de enriquecer suas decisões e de torná-las compatíveis à tradição de pensamento que justifica a própria existência do Estado. Assim, renova a visão que se tem sobre o burocrata, enxergando-o não como um cientista platonicamente sábio, mas como um agente republicano que deve deliberar à luz do interesse público concretamente aferido por meio de processos participativos. (Harvard Law Review 1994) Partindo da premissa que as agências são uma realidade, cumpre arguir pela sua intensa legitimação, sempre propugnando maior abertura de seus procedimentos de produção normativa e de participação democrática.

\section{Governança global e déficit democrático}

Paralelamente ao fenômeno da descentralização administrativa nos Estados ocidentais, ocorrido ao longo do século XX, os grandes conflitos mundiais pautaram a necessidade de uma maior cooperação internacional. Surgiu a Liga das Nações e, em seguida, a Organização das Nações Unidas; proliferaram-se as organizações não governamentais (ONGs) com atuação internacional; inúmeras agências especializadas foram criadas; instituições financeiras e regimes comerciais internacionais vieram ao primeiro plano.

O fortalecimento e a expansão da Organização das Nações Unidas, no segundo pós-guerra, bem como o relativo desprendimento ${ }^{11}$ de que ela passou a gozar na ordem internacional, foram os grandes motores para a mitigação do positivismo estatalista no plano internacional. ${ }^{12}$ As normas

\footnotetext{
${ }^{10}$ Tradução livre de: "Administrative agencies (...) may be the only institutions capable of fulfilling the civic republican ideal of deliberative decisionmaking."

${ }^{11}$ Por relativo desprendimento, entende-se o fato de que as agências especializadas da ONU não são meros braços de ação de um Estado. Quando um Estado adere a uma dessas organizações, compreende que sua vontade não prevalecerá necessariamente, ou seja, a organização se desprende, em parte, dele, para tornar-se o produto coletivo dos Estados que a alimentam.

12“A A inovação introduzida no Direito Internacional no final da II Guerra Mundial com a criação das Nações Unidas não tinha parecido aos primeiros prudentes Revista de Direito, Estado e Telecomunicações, v. 4, n. 1, p. 83-136 (2012) 
internacionais deixam de ser apenas mecanismos de autocontenção impostas pelos Estados a si mesmos e passam a ser comissivas, impondo comportamentos, refletindo o compartilhamento de outros valores, que passam a ser geradores de direito, e mitigando a ideia da vontade soberana estatal no plano mundial.

A partir do fim da bipolarização da geopolítica no mundo, com o término da Guerra Fria, as relações internacionais e o direito internacional aproximaram-se mutuamente e passaram a trabalhar com categorias que se comunicavam, fazendo uso, muitas vezes, de conceitos da filosofia política e da sociologia. Esse movimento marcou o que Barbara Woodward (2006) chama de passagem da internacionalidade para a globalidade. Enquanto a primeira trabalha com uma visão fragmentada das relações mundiais, contornadas pelas fronteiras dos Estados territoriais, a globalidade enxerga uma multiplicidade de relações de várias naturezas (políticas, sociais, econômicas e jurídicas) ocorrendo entre diversos níveis, a despeito das divisões formalistas entre Estados.

Quando se fala em governança global em um contexto jurídico, faz-se referência aos instrumentos regulatórios existentes no nível pós-nacional, sejam eles regras vinculantes, não vinculantes ou outros tipos de instituições. Há visões pessimistas associadas a isso. Alguns julgam que o uso da expressão governança global vem para mascarar e amaciar o fato de ONGs internacionais privadas estarem tomando o lugar dos Estados na determinação das políticas públicas; a governança, assim, estaria substituindo o governo. Outros argumentam que a autoridade dos Estados no plano internacional está sendo corroída pelas empresas multinacionais e pelos grandes grupos econômicos, que possuem influência decisiva e acesso

comentadores de tal monta que pudesse mudar a natureza inorgânica do Direito Internacional. A organização tinha sido considerada como um pacto entre os Estados membros, sustentado sim por instituições comuns, mas sem que estas pudessem se configurar como organismos acima dos Estados no plano geral. No entanto, bem cedo já se havia delineado uma discordância entre a tendência que considerava as Nações Unidas como um ordenamento particular entre os Estados membros, o que deixava inalterado o tradicional Direito Internacional comum, e aquela que entendia a organização como uma estrutura institucional do sistema geral, um complexo aparato de instituições que integrava o Direito Internacional comum." (ZICCARDI 2005, 211). 
privilegiado em certos organismos internacionais, como a OMC, o FMI e o Banco Mundial. (WOODWARD 2006)

Fala-se, hoje, em um direito global, que escapa ao direito doméstico; o primeiro é conceituado negativamente por Sundfeld (1999), em comparação com o segundo. $\mathrm{O}$ direito doméstico tem suas fontes dentro do Estado (constituição, leis, decretos,...), ao passo que o direito global tem-nas fora (tratados, normas de organismos internacionais, pseudonormas). O direito doméstico, ainda útil e sadio, tem seu conteúdo assediado por pressões econômicas externas. As normas estatais agora não levam mais em consideração apenas aspectos internos, mas necessidades mundiais, porquanto os mercados estão cada vez mais globalizados.

É possível perceber que, em muitos casos, o direito doméstico que parece ser genuinamente "feito em casa" é, na realidade, uma norma previamente trabalhada no âmbito das OIs por burocratas e especialistas internacionais e nacionais. Isso ocorre especialmente em relação às chamadas convenções-quadro que são emendadas continuamente, de acordo com os padrões do conhecimento especializado, no formato de protocolos ou recomendações, que, por sua vez, são implementadas, no seio doméstico, por meio de ordens executivas ou outras medidas regulatórias, abaixo do nível parlamentar, contornando 0 processo legislativo nacional. ${ }^{13}$ (DELBRÜCK 2003, 35-6) ${ }^{14}$

${ }^{13}$ Tradução livre do original: "In addition, one has to realize that, in many instances, domestic law that appears to be genuinely 'homemade' is actually nothing but a 'rubberstamped' regulation worked out at the level of IGOs by teams of international and national administrators (civil service). This is particularly true in the case of socalled framework conventions that are continuously amended according to the standards of expert knowledge, as either Protocols to conventions, or as recommendations that in turn are often implemented on the domestic level, through executive orders or other regulatory means, below the level of parliamentary legislation, thereby bypassing the national legislative process."

${ }^{14}$ Isso parece ser coerente com o papel das organizações intergovernamentais, porém se pode duvidar da relevância das organizações não governamentais (ONGs) internacionais no exercício de qualquer autoridade pública. Delbrück (2003), assim, esclarece que muitas delas têm participação privilegiada como consultoras especializadas em processos decisórios no âmbito das OIs, além de frequentemente figurarem como advogadas legítimas do interesse público internacional, ainda quem sem mandato democrático para isso.

Revista de Direito, Estado e Telecomunicações, v. 4, n. 1, p. 83-136 (2012)

DOI: https://doi.org/10.26512/lstr.v4i1.21576 
O principal descontentamento com a globalização decorre da percepção de que os governos locais ou nacionais estão perdendo poder para órgãos reguladores internacionais. Isso se associa ao fato de que tais órgãos são, com frequência, inacessíveis aos cidadãos comuns e irresponsáveis (unaccountable) perante eles, ou seja, os processos mediante os quais eles elaboram suas políticas e regras não são democráticos. (KINNEY 2002) O déficit democrático das Organizações Internacionais (OIs) tem sido cada vez mais combatido. Já não é recente o slogan "no globalization without representation". Mas, afinal, em que exatamente consiste o déficit democrático?

Steve Charnovitz (2003) admite três sentidos possíveis para essa expressão. Déficit democrático pode se referir ao fato de os organismos internacionais não tratarem igualmente todos os Estados que nele têm participação, dando oportunidades diferentes para eles se manifestarem e influenciarem suas decisões, conferindo, por exemplo, pesos diferentes aos seus votos. ${ }^{15}$ Déficit democrático pode também significar que as OIs não exigem que seus membros sejam Estados democráticos. A outra visão possível, que aqui se adota, é a de que déficit democrático faz referência ao fato de os organismos internacionais funcionarem afastados do público que é afetado por suas decisões.

Existem milhares de organizações internacionais hoje no mundo, a maior parte delas criada nas últimas décadas do século XX, de forma que qualquer espaço da atividade humana está sujeita a uma regulação internacional. Trata-se de um complexo sistema que desenvolve significativa autonomia em relação aos Estados instituidores. Essa autonomia é compensada pela participação dos Estados-membros nos processos decisórios, mas os organismos frequentemente admitem membros não estatais. São funções comuns a esses organismos a cooperação, a harmonização e a padronização entre Estados. ${ }^{16}$ (CASSESE 2005)

${ }^{15}$ É o que ocorre, por exemplo, no Conselho de Segurança da ONU. Evidentemente, sempre existirá a pergunta: devem ser aplicadas aos Estados dentro de uma OI as mesmas regras de participação democrática aplicáveis aos cidadãos em um Estado? ${ }^{16}$ Cassese (2005) nota que existe o seguinte padrão na organização desses órgãos: um corpo colegiado que reúne todos os membros, um colegiado mais restrito, eleito pelo 
A internacionalização da atividade administrativa - expressão que parece carregar um contrassenso - é verificada quando atividades até outrora exclusivas e típicas da Administração Pública nacional surgem além de suas fronteiras ou desconsiderando essas fronteiras. A norma que regulamenta essa atividade, portanto, deve seguir as máximas da legislação administrativa tipicamente nacional. Todavia, conforme já foi dito, o direito internacional tem muitas diferenças em relação ao direito nacional. Outras diferenças interessantes são a possibilidade de variação gradativa de efeito vinculativo - soft law, hard law - e a composição de fontes do direito. ${ }^{17}$ Nesse contexto, as normas internacionais secundárias surgem como uma formação jurídica intermediária, que acabam influenciando ou interferindo nos direitos nacionais. (AßMANN 2008) ${ }^{18}$

A dificuldade existente nessa internacionalização reside na seguinte questão: o que, afinal, em nível internacional, substituirá o porrete (big stick) de uma autoridade legislativa estatal? (SCHEUERMAN 2002) A multiplicidade das fontes do direito global e a ausência de uma autoridade unívoca ameaçam as bases do direito doméstico e atingem também o direito administrativo, à medida que tensionam a legalidade e a separação dos poderes:

Pela legalidade, diz-se, a Administração sujeita-se ao Parlamento; $\log 0$, à vontade popular. À medida que a lei vai perdendo seu posto de fonte primordial do direito administrativo, em favor das diretivas e de outras normas de origem externa, à medida que 0 Legislativo cede passo a órgãos internacionais (despidos de legitimidade popular), fragilizam-se as delicadas teias que sustentavam o direito administrativo: por um lado, a relação Legislativo/Administração, por outro, a relação lei/ato

primeiro, uma secretaria, que contém um corpo técnico permanente, e comitês permanentes ou ad hoc, para lidar com temas específicos.

${ }^{17} \mathrm{O}$ rol de fontes de direito internacional pode ser identificado no artigo 38 do Estatuto da Corte Internacional de Justiça e compreende convenções internacionais, costume internacional, princípios gerais de direito, decisões judiciais e doutrina dos publicistas mais qualificados.

${ }^{18}$ Assim como existe o debate sobre delegação legislativa no âmbito doméstico, relacionado à descentralização da produção normativa e de políticas públicas, corre o debate sobre a delegação internacional, por meio da qual países passariam a competência de decidir sobre políticas públicas para organismos internacionais.

Revista de Direito, Estado e Telecomunicações, v. 4, n. 1, p. 83-136 (2012)

DOI: https://doi.org/10.26512/lstr.v4i1.21576 
administrativo, justamente as que fazem do administrativo um direito subordinado. (SUNDFELD 1999, 166)

Para Sundfeld, porém, o direito administrativo não perde, afinal, suas bases, pois as medidas externas continuarão se submetendo ao direito interno, não importando que não se trate de lei aprovada pelo Legislativo nacional. Fazendo um uso intuitivo da ideia de liberdade como ausência de dominação, porém sem elaborá-la completa e profundamente, argumenta que o Estado de direito pode abrir mão do Legislativo, se for preservada a restrição ao exercício arbitrário do poder pela Administração. A lei faz esse papel, mas outra instituição pode assumi-lo em seu lugar. Os Estados ainda detêm boa parte das rédeas sobre o seu próprio direito. Por isso, Eberhard Schmidt-Aßmann julga que “(...) essa internacionalização deveria ser vista com normalidade pelo Estado (...) e não como um desenvolvimento radical imiscuindo-se e usurpando o seu domínio"19 (2008, 2068).

Os tratados internacionais e a legislatura nacional, portanto, ainda têm um papel relevante a desempenhar em relação a esse direito administrativo externo. São os tratados que conformam a autoridade para expedir normas secundárias e concedem-lhe a organismos. Isso significa que deve haver uma teorização da possibilidade de contestar normas que excedam os limites previamente estabelecidos, embora seja reconhecido que os tratados sejam, com frequência, suficientemente genéricos para albergar o maior número de casos relevantes vislumbrados. Igualmente, é a legislação nacional que faz a conexão institucional do direito internacional - seja primário, seja secundário - com o direito nacional, sob o manto da constituição. ${ }^{20}$

${ }^{19}$ Tradução livre de: "such internationalization should be considered normality for a constitutional state (...) and should not be viewed as a radical development intruding into and usurping the state's domain."

${ }^{20}$ De acordo com Celso Fernandes Campilongo (1999), a teoria do direito tem-se abalado com a globalização. A multiplicidade e a complexidade de relações jurídicas no plano global são tamanhas que muitos juristas têm procurado substituir o padrão piramidal de Kelsen, que identificava o direito com o Estado, por uma matriz em forma de teia de aranha, associando-se à ideia de pluralismo jurídico. Para o autor, essa mudança de perspectiva é indevida, porque o direito estatal, piramidal, não somente retém sua utilidade no novo momento, mas é um instrumento que merece ser fortalecido tanto para garantir a estabilização das expectativas no plano nacional, em face do lusco-fusco legal que os documentos oficiais internacionais representam, 
É nesse sentido que é ilegítimo a legislação nacional desresponsabilizarse de acoplar elementos democráticos nesse trânsito. Em outras palavras, é melhor confiar em procedimentos e mecanismos nacionais para se obter alguma legitimidade democrática dessas decisões do que confiar plenamente em ONGs que atuam internacionalmente junto aos organismos internacionais. $\mathrm{O}$ ambiente normativo nacional deve lidar com o fato de que os organismos internacionais vêm, mais e mais, exercendo atividades tipicamente administrativas com efeitos externos que, não raro, interferem em políticas nacionais e pressionam o país para alterar ordenamentos internos. (AßMANN 2008)

\section{Instituições republicanas brasileiras e o relacionamento com normas internacionais}

O ideal republicano de liberdade e de autogoverno, com o propósito de constituir um Estado livre, deu origem a uma plêiade de instituições que permanecem vigentes até hoje, em maior ou menor medida, tendo passado por mais ou menos alterações no curso da história. Alguns exemplos clássicos são a separação dos poderes, o sufrágio popular, o direito de ser votado e a alternância do governo; outros exemplos mais modernos são o processo administrativo, o direito a voz do cidadão perante o Poder Executivo e as instituições que concretizam a ideia de democracia participativa ou deliberativa. Todas essas instituições se tornaram basilares para o Estado republicano contemporâneo.

Além delas, existem outras, menos sublinhadas na literatura, que detêm o propósito de preservar o Estado livre diante do ambiente externo. Essas instituições garantem, entre outras liberdades, que as posições, os atos e os compromissos do Estado brasileiro para com o meio internacional tenham sido suficientemente debatidos e deliberados com algum grau de

quanto para a própria preservação da democracia. A respeito do risco de se perder a democracia construída institucionalmente no âmbito nacional, Campilongo afirma, em linguagem luhmanniana, que “(...) a globalização pode ser portadora de uma contratendência evolutiva na diferenciação funcional entre política e direito. Nos Estados em que essa diferenciação é apenas parcial, com o predomínio do sistema político, a globalização bloqueia a diferenciação".

Revista de Direito, Estado e Telecomunicações, v. 4, n. 1, p. 83-136 (2012)

DOI: https://doi.org/10.26512/lstr.v4i1.21576 
participação popular e de legitimidade. A inexistência dessas instituições levaria à sumária sujeição do Estado e do povo brasileiro ao ambiente exterior, a outros Estados e a outras forças externas com potencial de dominação. ${ }^{21} \mathrm{O}$ País perderia a liberdade republicana, isto é, cairia em condição análoga à de escravo, na medida em que estaria sujeito a interferências arbitrárias na condução comum de sua história e de suas decisões.

Pode-se afirmar que o arranjo institucional que carrega mais explicitamente esse fardo de proteção da liberdade republicana é o iter para internalização de tratados ancorado no texto constitucional. No Brasil, a competência para celebrar tratados, convenções e atos internacionais é privativa do Presidente da República e ainda se sujeita ao referendo do Congresso Nacional (CF, art. 84, VIII). Esses condicionamentos buscam garantir que as normas internacionais adotadas internamente pelo País não tenham menos legitimidade que as normas nascidas internamente.

A primeira fase nesse processo - em verdade, uma fase preliminar - é a da negociação do tratado internacional, em que seus termos são discutidos em todos os âmbitos - materialmente, formalmente e constitucionalmente. Isso ocorre, com frequência, por meio de conferências internacionais às quais comparecem delegações nacionais e por meio de grupos de trabalho multidisciplinares domésticos. A assinatura do tratado representa o primeiro passo na expressão do consentimento e é dado pelo chefe de Estado, pelo chefe de Governo, pelo ministro das relações exteriores, pelo chefe da missão diplomática ou por outro plenipotenciário, que porte uma carta de plenos poderes. Com a assinatura, em rigor, o comprometimento está perfeito e o tratado de condições de vigência imediata. Todavia, isso gera obrigações somente entre os signatários e ainda não internamente.

A Constituição Federal é clara ao atribuir ao Congresso Nacional - a casa do povo - o poder de "resolver definitivamente sobre tratados, acordos

\footnotetext{
${ }^{21}$ Alguns exemplos de instituições com esse propósito são o procedimento de internalização de tratados internacionais, a proibição de estrangeiros alistarem-se como eleitores, a proibição de partidos políticos receberem recursos financeiros do exterior e o condicionamento da propriedade de empresas jornalísticas e de radiodifusão a brasileiros natos ou naturalizados há mais de dez anos.
} 
ou atos internacionais que acarretem encargos ou compromissos gravosos ao patrimônio nacional" (art. 49, I).

A carta não inova por mencionar encargos ou compromissos gravosos ao patrimônio nacional: não há compromisso internacional que não os imponha às partes, ainda que não pecuniários. A prática recente, alcançando até os primeiros anos do novo século, prova que o governo e o parlamento brasileiros assim entendem: até mesmo tratados bilaterais para a mera dispensa de vistos em passaportes tem (sic) sido regularmente submetidos à aprovação do Congresso. (REZEK 2005, 60)

A aprovação do Congresso Nacional deve dar-se tanto pela Câmara dos Deputados quanto pelo Senado Federal e, se exitosa, resulta em um decreto legislativo. O Congresso pode adotar reservas à vigência de dispositivos do tratado no País, acrescendo-as às eventualmente já feitas pelo chefe do Poder Executivo. Em seguida, concluída a etapa parlamentar, o Presidente da República está livre para ratificar e promulgar o tratado, garantindo-lhe vigência na ordem interna mediante a sua publicação em decreto. Confirmar um tratado internacional pressupõe, assim, a presença necessária de três atos marcantes: a assinatura do tratado, a aprovação pelo Congresso e a ratificação pelo Presidente da República. (REZEK 2005)

A Constituição traz poucas disposições acerca da internalização de tratados, de forma que boa parte do direito relativo a esse tema é construído pela doutrina e pela jurisprudência. O Supremo Tribunal Federal manifesta posição estável de que o tratado internalizado no País alcança validade, eficácia e autoridade de lei ordinária, submetendo-se ao texto constitucional e permanecendo de igual para igual com outras leis federais. É, inclusive, passível de revogação quando lei posterior contradi-lo, conforme RE 80.004 .

Na ADI 1.480, o Min. Celso de Mello deixa claro que a concepção dualista sobre o direito internacional enxerga este e o direito interno como independentes e separados por limites claros. Isso, segundo o relator, refletese na existência de um procedimento especial para a internalização dos atos internacionais. Trata-se de uma visão dualista moderada, que não exige a promulgação de lei, mas o respeito a um iter procedimental insculpido na 
Constituição. A visão dualista opõe-se à perspectiva monista, que identifica um continuиm entre as ordens interna e internacional. ${ }^{22-23}$

A dogmática jurídica não tem evitado, contudo, que a economia, a política e o direito internacional influenciem, de fato, o direito nacional, buscando vias transversas de manifestação, algumas mais discretas, algumas mais explícitas. Segundo Oscar Vilhena Vieira (1999), os movimentos reformistas do Estado brasileiro dos anos 1990 foram resultados da importação das medidas do Consenso de Washington. ${ }^{24}$ Mudou-se o conceito de empresa nacional, flexibilizaram-se os monopólios estatais na prestação de serviços públicos e promoveram-se ou planejaram-se reformas estruturais, tudo com o objetivo alegado de criar condições adequadas para que o capital transnacional pousasse e se aninhasse no País. ${ }^{25}$

${ }^{22} \mathrm{~A}$ resistência do Brasil em deslocar sua cultura no sentido do monismo pode ser simbolizada pela redação dada ao $\S 3^{\circ}$ do art. $5^{\circ}$ pela Emenda Constitucional $n^{\circ} 45$, de 30 de dezembro de 2004. Essa alteração constitucional foi impulsionada por um grande desejo de parte da comunidade nacional de conferir mais força aos tratados e convenções internacionais sobre direitos humanos, equiparando-os a emendas constitucionais. O procedimento exigido, afinal, para isso foi duramente criticado, porquanto exige praticamente o mesmo rito previsto para aprovar emendas constitucionais comuns. Segundo os críticos, o conservadorismo ufanista na política brasileira tornou insossa a referida alteração constitucional.

${ }^{23}$ Segundo Gustavo Binenbojm (2000), a visão exposta pelos tribunais brasileiros foi considerada, pela doutrina, como monista moderada, embora aqueles a referenciassem como dualista moderada. Isso ocorre porque o monismo moderado e o dualismo moderado são versões híbridas de posições doutrinárias originais, desenhadas com critérios distintos. Enquanto o dualismo moderado concentra-se no fato de que a incorporação do tratado ao direito interno dispensa uma lei, adstringindo-se, entretanto, a um caminho processual apropriado, o monismo moderado salienta o fato de que o tratado equipara-se hierarquicamente a uma lei ordinária, estando sujeito ao mesmo regime de vigência - submissão à Constituição e revogabilidade pelo direito interno.

${ }^{24}$ Uma abordagem interessante e atual acerca das implicações do Consenso de Washington para o pluralismo institucional e para o multiculturalismo pode ser conferida em KELLEY (2010).

${ }^{25}$ Para tratar apenas de algumas, a Emenda Constitucional (EC) $n^{0} 5$, de 15 de agosto de 1995, permitiu a exploração do serviço local de gás canalizado por empresas privadas, a $\mathrm{EC}^{\circ}$ 6, do mesmo dia, removeu a exclusividade de exploração minerária 
A evolução do direito administrativo acompanha as nuances da relação entre Estado e mercado. Boa parte do direito administrativo atual, por exemplo, é fruto da tentativa do Estado de regular setores econômicos específicos, como os de serviços públicos e infraestrutura. (AMAN JR. 2002) A redução do papel prestacional do Estado e o correspondente aumento de seu papel supervisor da iniciativa privada implicou a adoção do modelo de agências reguladoras - autarquias em regime especial debruçadas sobre setores específicos da economia que se liberalizavam. ${ }^{26}$ Aqui se dará atenção especial à Agência Nacional de Telecomunicações (Anatel). ${ }^{27}$

Carlos Ari Sundfeld (2006), advogado atuante nos processos de reforma do Estado brasileiro da década de 1990, concorda, em boa parte, com Oscar Vilhena Vieira, na medida em que admite que o modelo adotado é apropriado a um regime de privatização e que o seu propósito inicial consistia em conferir segurança aos investidores estrangeiros. Acrescenta, ainda, que o Estado necessitava de mais agilidade para normatizar setores econômicos, não podendo apoiar-se única exclusivamente em disposições

e de potenciais de energia hidráulica por empresas brasileiras de capital nacional e deixou de tratar mais beneficamente as empresas de capital nacional de pequeno porte, a $\mathrm{EC}^{\circ}{ }^{\circ} 8$, também promulgada no mesmo dia, permitiu que empresas privadas explorassem serviços de telecomunicações e a $\mathrm{EC} \mathrm{n}^{\circ}$ 9, de 9 de novembro de 1995, flexibilizou o monopólio da União sobre atividades relacionadas à exploração de petróleo e de minerais nucleares. Nos dizeres de Carlos Ari Sundfeld (1999, 161), "os velhos serviços públicos, de regime jurídico afrancesado e explorados diretamente pelo Estado, estão desaparecendo, com as empresas estatais virando particulares e o regime de exploração dos serviços sofrendo sucessivos choques de alta tensão".

${ }^{26}$ A legislação brasileira exibe vários outros exemplos, como a Agência Nacional de Águas (ANA), a,Agência Nacional de Energia Elétrica (Aneel), a Agência Nacional do Petróleo, Gás Natural e Biocombustíveis (ANP) e a Agência Nacional de Transportes Terrestres (ANTT).

${ }^{27}$ Para uma abordagem da relação entre direito nacional e internacional no âmbito da aviação civil, com foco na atuação da Agência Nacional de Aviação Civil (ANAC), cf. OLIVEIRA (2011).

Revista de Direito, Estado e Telecomunicações, v. 4, n. 1, p. 83-136 (2012)

DOI: https://doi.org/10.26512/1str.v4i1.21576 
legais. Portanto, a agência surge como o instrumento de exercício da atividade normativa de conjuntura. ${ }^{28}$

Alexandre Santos Aragão constata que, de fato, o objetivo das leis instituidoras das agências é ser vaga, fazendo menção a princípios abstratos de pouca densidade normativa e conferindo “(...) um grande poder de integração do conteúdo da vontade do legislador” (ARAGÃO 2000, 287). Para compensar a deslegalização das matérias e a ampliação dos papéis do Poder Executivo por meio das agências reguladoras, aportaram-se significativas instituições de matiz republicano nessas recém-surgidas organizações. Audiências e consultas públicas, por exemplo, têm o propósito de garantir a oxigenação democrática dessas normas, a abertura cognitiva e a participação popular no processo de formulação. De acordo com Marcos Juruena Villela Souto $(2005,57)$, são as instituições dessa natureza que permitem a identificação dos interesses reais da sociedade, na ausência dos quais a norma seria ilegítima. ${ }^{29} \mathrm{O}$ panorama das agências reguladoras no direito brasileiro permite enxergá-las, por conseguinte, como

28" O fato é que, para realizar os interesses gerais da atualidade no contexto de um Estado intervencionista, não basta editar uma lei abstrata, genérica e distante, dizendo, por exemplo, que nenhuma exploração da atividade industrial pode ultrapassar certo limite de poluição, causando dano à saúde do vizinho. É preciso que o Estado vá trabalhando com a realidade todo o tempo, para definir, nas situações que se põem, o que é ou não uma emissão de poluentes aceitável; assim se obterá a paulatina diminuição da emissão de poluentes. É preciso impor graus crescentes de restrições à emissão de poluentes, e para isso a lei é insuficiente. Ninguém imagina que o legislador vá cuidar de regular o nível de emissão de poluentes no bairro do Maracanã no ano de 1998; e em janeiro de 1999 editar outra lei para estabelecer que já é hora de diminuir ainda mais o nível de emissão; e nova lei para voltar atrás. É viável supor que o legislador possa fazer isso, dedicando-se, ele próprio, a um verdadeiro gerenciamento normativo da realidade? Seria míope imaginá-lo. Nem o modo de produção de normas que conhecemos - que fez nascer o Código Civil nem o modelo tradicional de solução de conflitos - o do julgamento de ações judiciais pelo Judiciário - bastam nos novos tempos." (SUNDFELD 2006, 28)

${ }^{29}$ Aguillar (1999) ainda aponta que um tema cada vez mais presente nas discussões jurídicas atualmente é a participação popular em setores regulados, propiciando um controle social dos serviços públicos. Assim, é dever do Estado criar condições para a aproximação do usuário do serviço - o cidadão - desmistificando obstáculos técnicos e fomentando uma representação qualificada desse segmento. 
burocracias democrático-deliberativas, no sentido neorrepublicano. Elas são organizações criadas e preparadas para exercer esse papel, para constituir esse espaço.

Em alguns casos, a agência reguladora também passou a atuar de maneira efetiva nas pontes políticas e jurídicas com o ambiente internacional. Não se pode confiar cegamente na legitimidade democrática das normas produzidas pelos organismos internacionais. A maior parte deles exibe problemas de falta de abertura processual e de falta de participação, quando não de esvaziamento. ${ }^{30}$ Uma perspectiva democrático-deliberativa deve oferecer oportunidades amplas para a participação política e deve ensejar arranjos institucionais que estimulem essa participação. A distância a que as instituições internacionais posicionam-se do cidadão comum tornam-nas, naturalmente, pouco propícias a concretizarem uma democracia deliberativa. (MORAVCSIK 2004)

A saída para esse problema tem de passar pelo direito nacional, pois ainda é ele que pode garantir a existência e o funcionamento de instituições democrático-deliberativas. $\mathrm{O}$ que se propõe aqui é estudar de que forma a Anatel atua como espaço republicano na formação e na internalização de normas, decisões e pseudonormas oriundas de organizações internacionais. Ou seja, de que forma a Agência replica para o plano internacional o papel que lhe foi atribuído na formação de normas domésticas.

Uma visão como essa sobre a Anatel traz-lhe várias implicações. Uma implicação basilar dessa perspectiva, por exemplo, é que os delegados de cada país enviados para representá-lo em deliberações nos organismos internacionais não devem gozar - como de fato gozam hoje - de mais discricionariedade para decidir do que a discricionariedade que possuem nos processos de decisão no próprio país. Ou seja, cada plenipotenciário deve estar aberto à opinião pública e deve mediá-la republicana e deliberativamente antes de adotar uma posição. Ele deve, portanto, estar exposto a essas opiniões. ${ }^{31}$ (CHARNOVITZ 2003)

\footnotetext{
${ }^{30}$ Para um aprofundamento dessa questão, v. OLIVEIRA (2011).

${ }^{31}$ Charnovitz (2003) ainda radicaliza essa visão ao julgar que os plenipotenciários devem estar abertos até mesmo às ideias e às opiniões trazidas pelas entidades de outros países e nacionalidades. Assim, cada delegado funcionaria como um representante de todo o mundo.
}

Revista de Direito, Estado e Telecomunicações, v. 4, n. 1, p. 83-136 (2012)

DOI: https://doi.org/10.26512/1str.v4i1.21576 


\section{O setor de telecomunicações e as normas internacionais}

\subsection{Instituições republicanas na Anatel}

A institucionalização da Agência Nacional de Telecomunicações ocorreu em meio a várias garantias processuais e instituições republicanas. A Anatel serviu - e ainda serve - de modelo para muitas outras agências reguladoras criadas posteriormente. Pode-se dizer que sua criação serviu como um laboratório bem sucedido para uma renovação das instituições republicanas no Brasil; foi uma nova onda e uma nova perspectiva que se formou sobre a Administração Pública, o seu papel e suas responsabilidades democráticas.

Desde o seu anteprojeto, ainda sob a ousada configuração como Ofício Brasil de Telecomunicações ${ }^{32}$, já se previa a transparência e o alto grau de participação popular no funcionamento do órgão regulador. O projeto concebido pelo Sundfeld Advogados previa um grupo de dirigentes que não poderiam ser exonerados ad nutum, submeter-se-iam a uma quarentena quando deixassem o cargo e - um atributo fortemente republicano, pois garante a alternância do poder - não poderiam ser reconduzidos. Eles reunirse-iam e deliberariam em sessões abertas. Além disso, a normatização produzida pelo Ofício Brasil de Telecomunicações seria construída mediante procedimentos de participação democrática. $\mathrm{O}$ órgão regulador teria o papel, inclusive, de elaborar as políticas públicas para o setor. (PRATA, BEIRÃO e TOMIOKA 1999)

A decisão política de não inovar na categoria jurídica da Agência, instituindo-a como espécie do gênero autárquico, não significou a perda dos atributos originalmente planejados. Foram mantidas, por exemplo, ainda que formalmente, a independência administrativa, a ausência de subordinação hierárquica, o mandato fixo e a estabilidade de seus dirigentes e a autonomia financeira (Lei $\mathrm{n}^{\circ}$ 9.472, de 16 de julho de 1997, art. $8^{\circ}$, § $2^{\circ}$ ).

Ao motivar o desenho institucional do órgão regulador, a Exposição de Motivos $\mathrm{n}^{\circ}$ 231/MC, de 10 de dezembro de 1996, registrou

\footnotetext{
${ }^{32} \mathrm{O}$ Ofício Brasil de Telecomunicações constituía-se em uma nova categoria jurídica de entidade estatal, não estando ao regime comum das autarquias. Não seria parte integrante da Administração Pública, teria caráter fiducial e seria dotado de um alto grau de independência, incluindo financeira, não dependendo de recursos orçamentários do Poder Executivo.
} 
contundentemente a preocupação com a sua responsabilidade na prestação de contas (accountability) de ações tomadas com base em objetivos previamente definidos pelo Governo, sujeitas a controles subsequentes para comprovação do atingimento desses objetivos. Teve-se, ainda, uma preocupação explícita e central na formulação de mecanismos de pesos e contrapesos que evitassem que a decisão do órgão perseguisse outros fins que não o bem comum. Declarou-se fundamental que a Anatel:

disponha de regras e controles internos para limitar o poder das pessoas individualmente, de maneira a dificultar o comportamento oportunista e inibir ações indesejáveis por parte de operadoras e grupos de interesse. Exemplos dessas regras e controles são: decisão colegiada; processo de decisão variável em função do impacto da decisão (maior 0 impacto, maior 0 envolvimento colegiado na decisão); utilização de grupos consultivos; adoção do mecanismo de submeter a consulta pública os assuntos de maior relevância, antes da tomada de decisão; e período de carência entre a tomada de uma decisão e sua entrada em vigor, dando oportunidade às várias partes afetadas de se manifestar.

O propósito da existência de claras regras processuais na Administração Pública é (i) proteger os administrados, garantindo-lhes que terão voz antes de tomada a decisão administrativa, e (ii) permitir que a Administração adote uma decisão mais bem informada, na medida em que houve a sua oxigenação com opiniões e posturas diversas, manifestadas no processo. (MELLO 2009, 490-1) Quando a Agência foi criada, ainda não era uma praxe nos órgãos e entidades da Administração a existência de normas processuais claras ou padronizadas. Frequentemente os cidadãos que procuravam as portas do Poder Executivo enxergavam pouco ou quase nada da tramitação dos processos em que eram partes. A Constituição Federal já havia estendido o princípio do devido processo legal à esfera administrativa, mas isso ainda não se tinha concretizado de forma notória no então kafkiano ordenamento administrativo. ${ }^{33}$

${ }^{33}$ De acordo com Carlos Ari Sundfeld (Processo e Procedimento Administrativo no Brasil, 2006), no Brasil, o tema do processo administrativo apenas ganhou maior relevo a partir da década de 1970, tendo ficado boa parte do século XX relegado como simples formalidade ou solenidade de cumprimento opcional pela Administração e irrelevante para a validade dos atos administrativos. O processo Revista de Direito, Estado e Telecomunicações, v. 4, n. 1, p. 83-136 (2012) 
O primeiro ato normativo da Agência, a Resolução $\mathrm{n}^{\circ} 1$, de 17 de dezembro de 1997, cuidou de aprovar seu Regimento Interno. Este já previa várias instituições, procedimentos, etapas e prazos que viriam a ser consagrados cerca de um ano mais tarde, com a sanção da Lei $n^{\circ} 9.784$, de 29 de janeiro de 1999, que regula o processo administrativo da Administração Pública Federal até hoje. ${ }^{34}$ Nesse sentido, pode-se dizer que o Regimento Interno atual mantém um perfil próximo ao primeiro, exibindo um rico inventário de formas republicanas.

As instituições republicanas da Agência não se resumem a canais de participação política da população na formulação normativa setorial. Houve um ganho significativo na transparência dos procedimentos de outorga de serviços e de atribuição faixas de radiofrequência. Aos serviços prestados em regime privado, a autorização transformou-se em ato administrativo vinculado, não sujeito a juízo de conveniência e oportunidade pelo órgão ${ }^{35}$; aos prestados em regime público, foi estabelecida como necessária a realização de licitação para a escolha da empresa privada a tornar-se concessionária. A evolução na transparência dos processos de outorga de direito de uso de radiofrequência pode ser aferida comparando-se com a (in)existência dos mesmos procedimentos no âmbito do Ministério das Comunicações (MC), divisão essa gerada pela sujeição dos serviços de radiodifusão ainda ao Ministério. No âmbito da Agência, frequentemente ocorrem licitações para atribuição de faixas de radiofrequência e, nos muitos casos em que o espectro não mais representa um bem tão escasso e está sujeito à solicitação de uso por uma prestadora em específico, faz-se, ao

administrativo passou, então, a ser normatizado cada vez mais. $\mathrm{O}$ assunto foi definitivamente adensado com dois eventos: a Constituição Federal de 1988 e a Lei de Geral de Processo Administrativo Federal.

${ }^{34} \mathrm{O}$ Regimento Interno atualmente vigente foi aprovado pela Resolução da Anatel $\mathrm{n}^{\circ}$ 270, de 19 de julho de 2001.

${ }^{35}$ A Lei no 9.472/1997, nos arts. 132 e 133, condiciona a emissão de autorização para prestação de serviço em regime privado apenas ao preenchimento de requisitos objetivos (existência de projeto técnica e juridicamente viável e, quando for o caso, disponibilidade de radiofrequências) e subjetivos (ser empresa brasileira, não ter estado sujeita a determinadas punições pela Administração, dispor de capacidade técnica, econômica, financeira e estar adimplente com o fisco, além de não existir sobreposição de outorgas para o mesmo serviço na mesma área). 
menos, um chamamento público. ${ }^{36}$ No âmbito do $\mathrm{MC}$, há serviços de radiodifusão que, até muito recentemente, ainda eram atribuídos com base no puro arbítrio da Administração. ${ }^{37}$

A Anatel é dotada de instrumentos como consultas e audiências públicas, além do Conselho Consultivo. Ela também conta com o Comitê de Defesa dos Usuários de Serviços de Telecomunicações (CDUST), criado em 1999 e reativado recentemente. ${ }^{38}$ Há aspectos institucionais no modelo da Anatel que não foram preservados em outras agências e representaram uma perda de garantias republicanas; outras representaram um ganho.

À Anatel não se exige, em lei, a realização de audiências públicas, embora elas ocorram com frequência na discussão de matérias com razoável impacto regulatório. Por outro lado, não se submete ao juízo do Administrador realizar ou não uma consulta pública. Em vez de restringir a exigência deste procedimento a casos que preencham certos requisitos sempre sujeitos a manobras argumentativas -, a LGT é taxativa ao determinar que "as minutas de atos normativos serão submetidas à consulta pública, formalizada por publicação no Diário Oficial da União, devendo as críticas e sugestões merecer exame e permanecer à disposição do público na Biblioteca" (art. 42). Todos os documentos com eficácia normativa, portanto, devem passar pelo procedimento.

Consultas públicas não são apenas feitas para as resoluções da Agência. A LGT exige também, em seu art. 89, que, quando da realização de licitação para escolha de uma concessionária, seja submetida a críticas e sugestões do público a minuta de instrumento convocatório. Outros editais de licitação, comumente realizados para outorga de direito de uso de radiofrequência,

\footnotetext{
${ }^{36}$ Como a licitação é a regra para autorizar o uso de radiofrequências, o chamamento público funciona como uma etapa preliminar ao procedimento licitatório, destinado a verificar sua inexigibilidade e a apurar o número de interessados na exploração de serviço ou uso de radiofrequências (Regimento Interno, art. 46, caput).

${ }^{37}$ Este certamente não era mais o caso das grandes operações de radiodifusão comercial, mas o caso ainda, por exemplo, da Radiodifusão Educativa. A esse respeito, vide: LIMA (2007).

${ }^{38}$ O Conselho de Defesa dos Usuários de Serviços de Telecomunicações (CDUST) foi criado pela Resolução n 107 , de 26 de junho de 1999, para assessorar o Conselho Diretor em matéria de controle, prevenção e repressão das infrações dos direitos dos usuários.
} 
também têm suas minutas submetidas a consulta pública, de acordo com o que define o art. 10 do Regulamento de Licitação para Concessão, Permissão e Autorização de Serviço de Telecomunicações e de Uso de Radiofrequência, aprovado pela Resolução da Anatel $n^{\circ}$ 65, de 29 de outubro de 1998.

A consulta pública, prevista em lei, foi ampliada no Regimento Interno, abrangendo não só os atos normativos, mas qualquer outro que envolva interesse relevante. O prazo mínimo para a consulta pública é de dez dias, devendo a Agência aplicar o princípio da proporcionalidade na fixação do prazo para cada caso. Embora seja perceptível que isso não ocorre de forma coerente - não é raro casos mais simples ou menos impactantes submeterem-se a períodos mais longos de consulta do que casos mais complexos ou relevantes ${ }^{39}$-, a previsão de um prazo mínimo é uma garantia republicana que a Administração não pode combalir.

Os atos normativos, segundo o Regimento Interno, são as resoluções, portanto são estas cujas minutas submetem-se ao rito da consulta pública. ${ }^{40}$ A iniciativa do procedimento normativo na Anatel, caracterizada como uma minuta de resolução, não é privativa, podendo ser de algum órgão da

\footnotetext{
${ }^{39} \mathrm{Um}$ caso notório em que isso ocorreu foi o prazo total de menos de 45 dias concedidos à Consulta Pública n ${ }^{\circ} 23 / 2008$, que propunha a revisão do Plano Geral de Outorgas do Serviço Telefônico Fixo Comutado (PGO-STFC), destoando de prazos maiores conferidos a propostas aparentemente menos relevantes, como, por exemplo, a Consulta Pública $n^{\circ} 755 / 2006$, que veiculou proposta de alteração no Plano Geral de Autorizações do Serviço Móvel Pessoal (PGA-SMP) e durou cerca de 70 dias. ${ }^{40} \mathrm{~A}$ qualificação jurídica da resolução como o instrumento normativo da Anatel, como já se disse, implica o fato de elas sempre serem submetidas a consultas públicas. No entanto, isso não tem evitado casos em que outros tipos de atos, não sujeitos a consulta pública, tenham nítido caráter normativo. Isso ficou bem evidente, por exemplo, quando na emissão do Despacho no 172/2004/PBCP/SPB, no âmbito de um processo administrativo concreto, que determinou aos grupos Telemar, Brasil Telecom e Telesp que disponibilizassem aos grupos Embratel e Intelig, bem como a qualquer outra prestadora que solicitasse, “(...) os elementos desagregados da rede de acesso local do STFC sob as modalidades de Compartilhamento do Enlace Local (Line Sharing) e Desagregação Plena do Enlace Local (Full Unbundling)". São também notórios casos, aqui não especificados, em que ofícios circulares são encaminhados a prestadoras veiculando normas de conduta a serem cumpridas, fundadas ou não em dispositivos normativos propriamente ditos.
} 
Agência, de algum membro do Conselho Diretor, do Poder Executivo, do Conselho Consultivo ou de qualquer pessoa física ou jurídica, na medida em que analisada previamente pelo órgão competente para a matéria. "O Conselho Diretor é obrigado a, antes de editar a resolução, examinar as críticas e sugestões encaminhadas em virtude da Consulta Pública, devendo expor em documento próprio as razões para a adoção ou não das medidas (...)" (art. 50).

A execução dessa tarefa pela Agência tem demonstrado significativa evolução ao longo do tempo. A partir de 1999, por exemplo, quase todas as consultas públicas realizadas constam registradas em seu sítio da Internet, com o texto original, as contribuições recebidas e, algumas vezes, a resposta às contribuições. A indisponibilidade da resposta da Agência às contribuições ainda é um elemento que prejudica a formação de uma espiral participativa e o caráter republicano do procedimento. A cultura de participação é dificultada em razão do fato de a ausência de resposta induzir o cidadão ao pensamento de que a contribuição foi em vão. Esvai-se o caráter republicano, na medida em que não se pode averiguar se as decisões normativas da Anatel apoiam-se ou não em razões publicamente reconhecidas. Apesar disso, a partir da análise das respostas disponíveis, é notório o aumento da densidade das fundamentações da Administração para acatar ou não alguma contribuição. Inicialmente, pouco mais de uma linha era dispensada para justificar, em termos abstratos, o não acolhimento ou a recepção. Nas consultas públicas mais recentes, porém, as fundamentações têm-se mostrado cada vez mais concretas, o que evidencia a progressiva abertura argumentativa e deliberativa do órgão.

Outro instrumento republicano de participação e debate político na formação dos atos normativos da Agência é a audiência pública. Trata-se de um procedimento voluntário - não é vinculado legal ou normativamente a qualquer iniciativa ou ato - orientado ao debate oral de matéria de interesse geral. A convocação para uma audiência pública é feita, pelo menos, cinco dias antes de ocorrer e configura-se uma reunião pouco formal. O debate é posteriormente registrado e disponibilizado para o público na Anatel. Embora a realização de audiências públicas seja meramente voluntária, elas são frequentemente realizadas por ocasião de consultas públicas relacionadas a minutas de regulamento ou de decretos. 
O Conselho Consultivo da Anatel tem previsão e desenho institucional delineado em lei, conferindo mais garantias ao funcionamento desse mecanismo de contrapeso político potencialmente poderoso. Compõem o Conselho Consultivo da Anatel representantes indicados pelo Senado Federal, pela Câmara dos Deputados, pelo Poder Executivo, pelas associações ou sindicatos empresariais do setor, por associações ou entidades defensoras dos direitos dos usuários e por entidades gerais da sociedade civil.

Por um lado, o Conselho Consultivo da Anatel projeta a importância transversal que o setor de TICs vem adquirindo na sociedade contemporânea. A telecomunicação não é mais vista como um serviço em si mesmo, para o qual se debruçam apenas as atenções dos atores tecnicamente vinculados especificamente ao setor. Ela é vista hoje, sobretudo em função da popularização da Internet, como um instrumento mais amplo para a cidadania, o crescimento econômico e a democratização de oportunidades econômicas e educativas. A inserção como membro do Conselho Consultivo de, genericamente, entidades representativas da sociedade é um forte reconhecimento dessa transversalidade.

Por outro lado, a inserção de representatividade do Poder Legislativo e do Poder Executivo arrisca desvirtuar o propósito do Conselho Consultivo como entidade de representação direta de interesses socialmente difusos. Esse risco fica ainda mais evidente quando a regulamentação previu que esses representantes ocupariam seis das doze vagas no Conselho. Pela força dos mecanismos institucionais republicanos de freios e contrapesos já existentes, parece prescindível a ocupação dessas vagas por esses poderes; eles possuem outros mecanismos, institucionais e não institucionais, de exercer influência sobre as decisões da Agência. Em seu lugar, seria bemvinda uma maior segmentação de interesses específicos do setor de telecomunicações.

O Conselho Consultivo da Anatel é dotado de relativa independência e influência, porquanto a lei já lhe garante manifestações, prévias ao encaminhamento ao Poder Executivo, no curso do processo de formulação do Plano Geral de Outorgas (PGO), do Plano Geral de Metas de Universalização (PGMU), de qualquer outra política governamental de 
telecomunicações e na instituição ou eliminação de serviço prestado em regime público. ${ }^{41}$

O CDUST foi criado diante da percepção de que o usuário é o elo mais fraco do setor, merecendo, assim, um espaço institucional maior. Todavia, seu funcionamento tem sido bastante irregular desde a sua criação, o que enfraquece significativamente sua influência nas decisões da Agência. O Conselho, que é secretariado pelo Chefe da Assessoria de Relações com os Usuários, é composto por servidores da própria Agência e por representantes dos usuários segmentados pelos serviços de telefonia fixa de uso coletivo e de uso individual, de serviços móveis, de serviços de comunicação de massa, de outros serviços, além de representante de entidade de classe das prestadoras de serviços de telecomunicações.

Diversamente do que se dá em outros setores regulados, a Agência Nacional de Telecomunicações não se sujeita a políticas públicas emitidas por um órgão específico. A produção de políticas é difusa e isso é retratado no próprio art. $1^{\circ}$ da LGT: "Compete à União, por intermédio do órgão regulador e nos termos das políticas estabelecidas pelos Poderes Executivo e Legislativo, organizar a exploração dos serviços de telecomunicações”. O papel do Ministério das Comunicações na elaboração de políticas de telecomunicações ficou fortemente retraído após a criação da Anatel. Decisões com intenso teor político que precisavam ser tomadas no setor eram feitas - e ainda o são, de certa maneira - de forma embutida na aparência técnica da regulação feita pela Agência. A ausência do exercício, pelo Ministério, de seu papel formulador, perdurou até 2003, quando foi criada, no MC, a Secretaria de Telecomunicações. A esta se incumbiu, entre outras, a atividade de "formular, propor políticas e diretrizes, objetivos e metas, relativos aos serviços de telecomunicações" (art. 11, I, da Estrutura Regimental do Ministério das Comunicações, aprovada pelo Decreto $\mathrm{n}^{\circ}$ 4.635, de 21 de março de 2003).

O Ministério, então, não tardou a formular um conjunto de políticas públicas de telecomunicações e veiculá-las por meio do Decreto n ${ }^{\circ} 4.733$, de

\footnotetext{
${ }^{41}$ Além dessas competências específicas, o art. 35 da LGT ainda define como competência do Conselho Consultivo apreciar os relatórios anuais do Conselho Diretor e requerer informação e fazer proposição a respeito do exercício das competências do Conselho Diretor.
}

Revista de Direito, Estado e Telecomunicações, v. 4, n. 1, p. 83-136 (2012)

DOI: https://doi.org/10.26512/lstr.v4i1.21576 
10 de junho de 2003. Todavia, a competência do MC para isso não é propriamente exclusiva. Essa difusão de polos produtores de políticas pode ser apontada, como já dito, na troca de metas de universalização, de 2008, e no Programa Nacional de Banda Larga (PNBL), de 2010. Evidentemente, essa dispersão prejudica o acompanhamento, pelos cidadãos, dos processos de produção de políticas públicas, notadamente quando insere órgãos pouco preparados institucionalmente a prover uma abertura participativa.

Ministério das Comunicações, Casa Civil e Presidência da República carecem notadamente de garantias republicanas como a consulta e a audiência pública. Apesar disso, não se mostram insensíveis quanto à necessidade de enriquecer suas decisões com o debate público. Em 24 de abril de 2008, o MC lançou consulta pública destinada a rever as políticas públicas de telecomunicações (Ministério das Comunicações 2008). Ao cabo de 2009, foi organizada a $1^{\text {a }}$ Conferência Nacional de Comunicação (Confecom), que convocou a sociedade civil organizada para discutir e deliberar acerca de uma série de temas no plano da política de comunicações. ${ }^{42}$ No acompanhamento, no debate e na formulação das ações do PNBL, foi criado o Fórum Brasil Conectado, voltado a promover o diálogo da sociedade civil organizada com os órgãos governamentais.

\subsection{Anatel e normas internacionais}

Pôde-se verificar que, no setor de telecomunicações nacional, a busca por meios de legitimar a produção de políticas e de normas infralegais é intensa. Isso tem ocorrido por meio de consultas públicas, audiências, conselhos, conferências e fóruns. Em que medida essa preocupação é capaz de se imprimir às normas e pseudonormas internacionais no momento em que elas passam a viger no País?

Sabe-se que a União Internacional de Telecomunicações (UIT) atua de duas formas na cooperação internacional no setor de telecomunicações. Ela emite regulamentos administrativos ${ }^{43}$, que são vinculantes a todos os países

\footnotetext{
${ }^{42} \mathrm{~A}$ respeito dos debates, das deliberações e dos encaminhamentos da Confecom, v. Ministério das Comunicações (2010).

${ }^{43}$ Os dois principais regulamentos administrativos são o Regulamento das Telecomunicações Internacionais (RTI) e o Regulamento de Radiocomunicações (RR).
} 
convenentes e, também, chancela ou formula recomendações relacionadas à normalização de redes e equipamentos de telecomunicação, para garantirlhes interoperabilidade. As decisões da UIT a respeito da alocação de determinada faixa do espectro de radiofrequências ou sobre a padronização de determinado protocolo de comunicação possuem tremendo impacto sobre os mercados; a pena da Organização é capaz de definir vencedores e perdedores em escala global.

A coordenação internacional feita pela UIT é essencial para o setor e um instrumento imprescindível para as telecomunicações contemporâneas. Se realizada de maneira aberta, participativa e transparente, o tipo de atividade desempenhada pela UIT leva a fortes e legítimas decisões que facilitam o acesso de todos os países às telecomunicações, permitindo que as trocas internacionais de informações ocorram de maneira transparente e a baixo custo para todos e que a indústria de equipamentos e aparelhos de telecomunicações tenha escala suficiente para induzir o barateamento dos terminais e colaborar para a massificação dos serviços. Todavia, se essa atividade não for desempenhada de forma inclusiva e participativa, com o forte envolvimento de todos os atores globais que, por essência, serão impactados pelas deliberações, ela torna-se um instrumento de dominação.

Com o propósito de garantir a legitimidade dessas decisões, tendo por incerta a legitimidade dos procedimentos internacionais de criação normativa, o Código Brasileiro de Telecomunicações (CBT) dispunha:

Art. $2^{\circ}$ Os atos internacionais de natureza normativa, qualquer que seja a denominação adotada, serão considerados tratados ou convenções e só entrarão em vigor a partir de sua aprovação pelo Congresso Nacional.

Parágrafo único. O Poder Executivo enviará ao Congresso Nacional no prazo de 180 (cento e oitenta) dias, a contar da data da assinatura, os atos normativos sôbre telecomunicações, anexando-lhes os respectivos regulamentos, devidamente traduzidos.

Art. $3^{\circ}$ Os atos internacionais de natureza administrativa entrarão em vigor na data estabelecida em sua publicação depois de aprovados pelo Presidente da República (art. 29, al).

Esses dispositivos são perfeitamente alinhados à concepção republicana de Estado livre e às instituições criadas para concretizá-la no País. Sendo o 
Congresso Nacional o epicentro do autogoverno e considerando que o procedimento de internalização de tratados é o que confere legitimidade democrática à vigência dos atos internacionais no País, a previsão do uso desse instrumento para as normas da UIT ou de quaisquer outros organismos internacionais mostra-se coerente $^{44}$ Ao Conselho Nacional de Telecomunicações (CONTEL) competia estudar os temas debatidos em reuniões internacionais e sugerir e propor diretrizes para as delegações brasileiras, além de opinar antes da aprovação dos atos internacionais pelo Presidente da República.

De acordo com o que já se apontou, a Lei no 9.772/1997 (Lei Geral de Telecomunicações - LGT), juntamente com a $\mathrm{EC} \mathrm{n}{ }^{\circ}$ 8/1995, promoveu e consolidou definitivamente a descentralização regulatória e a deslegalização de uma série de temas no âmbito das telecomunicações. Esse movimento não deixou incólume a relação jurídica do Estado brasileiro com o mundo. A Lei Geral trouxe, também, uma clara mudança na abordagem dos documentos normativos internacionais.

A polarização entre assessoria interna e representação do Brasil em fóruns internacionais inverteu-se. Se, antes, a representação dava-se univocamente pelo Poder Executivo com a assistência do órgão setorial, agora compete à Agência representar o Brasil nos organismos internacionais de telecomunicações, sob a coordenação do Poder Executivo.

A atividade de gerir a alocação e as condições de uso do espectro de radiofrequências, por outro lado, passou a estar expressamente conferida à Anatel. A ela compete elaborar o plano de atribuição, destinação e distribuição de faixas de frequências no Brasil, observando os compromissos internacionais. Apesar disso, a regulamentação internacional continua sendo determinante, conforme revela o art. 161 da própria LGT

\footnotetext{
${ }^{44}$ Antes da promulgação do CBT, esse era o procedimento utilizado para os regulamentos da UIT, conforme demonstra o Decreto $\mathrm{n}^{\circ} 48.700$, de 4 de agosto de 1960, que aprovou os Regulamentos Telegráfico e Telefônico anexos à Convenção Internacional de Telecomunicações. O próprio veto do Presidente João Goulart ao art. $3^{\circ}$, posteriormente revigorado pelo Congresso Nacional, declarava: "Os atos internacionais, firmados que são por delegações plenipotenciárias, ficam sujeitos, de acôrdo com a Constituição, ao referendum do Congresso. Não interferem em matéria administrativa, como é óbvio" (Mensagem no 173, de 1962).
} 
(grifo ausente no original): "A qualquer tempo, poderá ser modificada a destinação de radiofreqüências ou faixas, bem como ordenada a alteração de potências ou de outras características técnicas, desde que o interesse público ou o cumprimento de convenções ou tratados internacionais assim o determine".

Como passou a ser tratada a internalização dos atos normativos internacionais com o novo Estatuto? O tema caiu em um limbo jurídico, na medida em que a LGT não o tratou expressamente. Ainda dificulta encontrar uma resposta para essa questão o fato de o CBT não ter sido totalmente revogado e de não terem sido apontados quais dos seus artigos continuam ou não vigendo. A Lei $\mathrm{n}^{\circ} 4.117 / 1962$, em verdade, foi revogada, porém a Lei ${ }^{\circ}$ 9.472/1997 ressalvou "(...) a matéria penal não tratada nesta Lei e (...) preceitos relativos à radiodifusão". Em rigor, portanto, os dispositivos da CBT que tratam das relações normativas internacionais do Brasil não estão mais vigentes - exceto, talvez, no que se refira à radiodifusão.

A Constituição e a Convenção da UIT foram promulgadas, pela primeira vez, no País, por meio do Decreto $n^{\circ} 41.949$, de 2 de agosto de 1957. A sua última versão foi promulgada pelo Decreto $\mathrm{n}^{\circ} 2.962$, de 23 de fevereiro de 1999. Não houve reservas ao texto e o Brasil aderiu, portanto, a todas as suas cláusulas. A Constituição da UIT atribui expressamente caráter vinculativo aos Regulamentos Administrativos. A promulgação dos atos constitutivos da UIT, portanto, implica, ao menos em tese, a aceitação de todos os seus procedimentos e dos atos vinculativos subsequentes, previstos nas disposições constitucionais.

A Anatel incorpora as Resoluções do Mercosul ao ordenamento jurídico nacional por meio de suas próprias Resoluções, que passam por consulta pública. ${ }^{45}$ Isso, todavia, não ocorre explicitamente com os Regulamentos nem com as Recomendações da UIT. A UIT tem procedimentos que parte considerável da doutrina reconhece como democráticos. No entanto, a sociedade nacional precisa ter meios concretos de participação na formulação dessas normas desde o seu início. A partir do momento em que a Agência adquiriu poder normativo sobre o setor econômico de

\footnotetext{
${ }^{45}$ Vide, por exemplo, a Resolução da Anatel $n^{0}$ 41, de 24 de julho de 1998, a Resolução da Anatel no 219, de 24 de março de 2000, e a Resolução da Anatel $\mathrm{n}^{\circ}$ 336, de 24 de abril de 2003.
}

Revista de Direito, Estado e Telecomunicações, v. 4, n. 1, p. 83-136 (2012)

DOI: https://doi.org/10.26512/lstr.v4i1.21576 
telecomunicações, posicionou-se como burocracia democrático-deliberativa setorial, criando o espaço para a ampla participação dos cidadãos nas suas decisões. Viram-se os mecanismos institucionais que concretizam isso para os atos gerados internamente. Como essa exigência institucional passou a ser exercida para as normas e pseudonormas da UIT?

Em 28 de janeiro de 1999, a Resolução da Anatel $n^{\circ} 95$ criou as Comissões Brasileiras de Comunicações (CBCs), com o objetivo de fazer a Administração brasileira atuar coordenada e integradamente nos foros internacionais de telecomunicações, respondendo às questões de interesse nacional. Um ano mais tarde, republicou-se seu Regimento Interno (Resolução $\mathrm{n}^{\circ}$ 214, de 16 de fevereiro de 2000), que foi revogado pelo Regimento aprovado pela Resolução $\mathrm{n}^{\circ} 347$, de 22 de agosto de 2003, vigente até hoje. Entre as atividades desempenhadas pelas CBCs, estão o estudo de questões e a preparação de propostas de contribuição ou das posições brasileiras em fóruns internacionais e o acompanhamento e a colaboração com os trabalhos da UIT, da Comissão Interamericana de Telecomunicações (Citel), do Mercosul, da OMC, do Fórum da Governança da Internet (IGF - Internet Governance Forum), da ICANN, da Comunidade de Países de Língua Portuguesa (CPLP) e do Foro Latinoamericano de Entes Reguladores de Telecomunicações (Regulatel).

A larga atuação das CBCs em fóruns internacionais, que, antigamente, resumiam-se praticamente à UIT, revela a constelação de organismos internacionais com poder de regulação sobre o setor de telecomunicações. Em 18 de abril de 2008, sua estrutura organizacional foi alterada, por meio da Resolução $n^{\circ}$ 502. Existem hoje quatro CBCs. A CBC 1 (Governança e regimes internacionais) participa e posiciona o Brasil nos fóruns deliberativos internacionais de normalização, desenvolvimento, políticas de telecomunicações e acordos comerciais internacionais, coordenando-se internamente com o Ministério das Relações Exteriores (MRE) e com o Comitê Gestor da Internet no Brasil (CGI.br). A $\mathrm{CBC} 2$ (Radiocomunicações) tem atuação voltada à gestão e à utilização do espectro de radiofrequências, participando preponderantemente dos órgãos competentes da UIT e do Mercosul. A CBC 3 (Normalização de telecomunicações), que atua sobretudo no UIT-T, na Citel e no Mercosul, colaborando com a fixação de padrões e a interoperabilidade de redes e equipamentos. A CBC 4 (Desenvolvimento das Telecomunicações) trabalha 
com assuntos relacionados ao desenvolvimento das telecomunicações nacionais e ao desenvolvimento do País por meio das telecomunicações, contribuindo, por exemplo, com a CPLP e com outros países em desenvolvimento. ${ }^{46}$

As CBCs não são compostas apenas por membros oriundos da estrutura estatal, estando abertas à participação de pessoas físicas e jurídicas, públicas e privadas, conforme dispõe o Regimento Interno (V, 2): "A participação nas CBCs será aberta aos segmentos público e privado com interesse direto no setor de telecomunicações, assim como a especialistas que possam prestar colaboração nesta área". Todavia, como se nota, a acessibilidade à participação não é a mesma da que ocorre em uma consulta ou em uma audiência pública. Qualquer participante deve ser previamente aprovado, sob o crivo de ter interesse direto no setor de telecomunicações. Não há definição para "interesse direto", mas, hoje, participam das CBCs, basicamente, entidades acadêmicas e empresas, além de funcionários do Estado.

As CBCs encarnam, mal ou bem, o papel institucional do órgão regulador no contexto de uma democracia contestatória de cunho republicano. Elas são canais de formulação e de participação prévia. Isso permite que a decisão gerada internacionalmente, vinculativa ou não, carregue uma maior legitimidade quando aplicada no País, porquanto já esperada, refletida e posicionada no mapa regulatório dos atores setoriais.

Não há, por outro lado, registro recente de uma aplicação imediata de algum documento internacional no País, por mais que tenha caráter vinculativo. Frequentemente, porém, as recomendações de normalização e o Regulamento de Radiocomunicações da UIT orientam a atividade de certificação e homologação da Agência e pré-condicionam a alocação e a regulamentação de faixas do espectro de radiofrequências.

\footnotetext{
${ }^{46}$ Eventualmente são criadas CBCs Temporárias, que visam a preparar a posição brasileira para certas ocasiões, frequentemente relacionadas à ocorrência das Conferências Mundiais da UIT.
} 


\subsection{Estudo de casos}

\subsubsection{International Mobile Telecommunications (IMT) 47}

O padrão International Mobile Telecommunications (IMT), cunhado no âmbito do Setor de Radiocomunicações da UIT (UIT-R) e refletido no Regulamento de Radiocomunicações (RR) e em recomendações, talvez seja o exemplo mais claro do impacto das decisões da União Internacional de Telecomunicações no País. A criação do IMT fundamenta-se na ideia de uma padronização mundial de protocolos, de faixas de frequência e de políticas regulatórias que levasse a um ganho de escala na produção de equipamentos - sobretudo, estações rádio base e estações terminais - e a uma convergência de fabricantes, tecnologias e operadoras. ${ }^{48}$ Essa harmonização permitiria a rápida disseminação dos serviços móveis em função do baixo custo de produção alcançado e induziria à diminuição do hiato entre países desenvolvidos e países em desenvolvimento.

O IMT é objeto de deliberação a cada duas Conferências Mundiais de Radiocomunicação (CMRs). A concepção do padrão iniciou-se em 1994, sob o nome Future Public Land Mobile Telephony System (FPLMTS). Foram, então, prospectadas dezenas de tecnologias que poderiam ser avalizadas pelo padrão. $\mathrm{O}$ desafio consistia, entre outros, em conceber um sistema que provesse transmissão de dados em alta velocidade, qualidade de voz similar à telefonia fixa e roaming global (União Internacional de Telecomunicações 2001-2002).

Apresentada a demanda, procuraram-se os sistemas capazes de supri-la, a quantidade de espectro de radiofrequências necessária para atendê-la, quais faixas seriam as candidatas e, para escolhê-las, uma análise do

\footnotetext{
${ }^{47} \mathrm{O}$ relato e a análise deste caso não seriam possíveis sem a valiosa colaboração de Maximiliano Salvadori Martinhão.

${ }^{48}$ Embora o trabalho sobre o International Mobile Telecommunications (IMT) tenha sido conduzido principalmente no UIT-R, que é responsável pelo estabelecimento dos planos de radiofrequência e pela fixação de certos padrões de equipamentos de rádio, também houve o envolvimento com o UIT-D, que desenvolveu manuais para países em desenvolvimento realizarem as transições tecnológicas e prepararem-se regulatoriamente, e com o UIT-T, que trabalhou na normalização dos sistemas de comunicação, modulação, compressão de voz, usos de tunelamento, entre outros aspectos ancilares do IMT.
}

Revista de Direito, Estado e Telecomunicações, v. 4, n. 1, p. 83-136 (2012) 
impacto regulatório. Elaborado o relatório ao longo dos anos seguintes, a definição da terceira geração da telefonia móvel (3G) ocorreu na CMR de 2000 e marcou a mudança da nomenclatura de FPLMTS para IMT-2000. Para o 3G, fixaram-se as faixas de radiofrequência de 800, 900, 1.800, 1.900 e $2.100 \mathrm{MHz}$. Cinco interfaces foram padronizadas, de acordo com a Recomendação UIT-R M.1457, aprovada em maio de 2000: Code Division Multiple Access (CDMA2000), Wideband CDMA (WCDMA), Time Division and Space Code Multiple Access (TD-SCDMA), Universal Wireless Communication-136 (UWC-136) e Digital Enhanced Cordless Telecommunications (DECT).

$\mathrm{Na}$ CMR de 2003, fabricantes e operadoras levaram o pleito por novas faixas de radiofrequência, na medida em que as faixas do IMT-2000 mostravam-se insuficientes diante das projeções de utilização do espectro no tempo. Uma das resoluções da CMR 2003 foi, portanto, prospectar novas faixas de radiofrequência para o IMT. O roteiro de trabalho padrão foi seguido até a Conferência seguinte e o relatório produzido no período foi apresentado e deliberado na CMR de 2007.

No relatório, propunha-se que as bandas de radiofrequência candidatas situassem-se entre as faixas de 400 e $5 \mathrm{GHz}$ e indicavam-se, por conseguinte, as seguintes: $410-30 \mathrm{MHz}, 450-70 \mathrm{MHz}, 470-806 / 862 \mathrm{MHz}$, 2,3-2,4 GHz, 2,7-2,9 GHz, 3,4-4,2 GHz e 4,4-4,99 GHz. (União Internacional de Telecomunicações, Setor de Radiocomunicações 2007) Como resultado da CMR, o IMT-2000 deu lugar ao IMT-Advanced e nasceu a quarta geração de tecnologia móvel $(4 \mathrm{G})$. Foram identificadas e fixadas faixas do espectro de radiofrequências em âmbito mundial e em âmbitos regionais. Mundialmente, padronizaram-se as faixas de $450-70 \mathrm{MHz}$ e de 2,3-2,4 GHz; regionalmente, nas Américas, foram padronizadas as faixas de $700 \mathrm{MHz}\left(698-806 \mathrm{MHz}\right.$ ) e de 3,4-3,6 GHz ${ }^{49}$ (União Internacional de Telecomunicações, Setor de Radiocomunicações 2008). Os atos finais da CMR também contiveram disposições acerca da faixa de 2,5-2,7 GHz para o IMT. Em 2010, um grupo de trabalho do UIT-R reconheceu apenas duas interfaces como aptas a se enquadrarem nos critérios de 4G: Long Term

\footnotetext{
${ }^{49} \mathrm{~A}$ padronização da faixa de $3,4-3,6 \mathrm{GHz}$ foi feita, praticamente, em âmbito mundial, porquanto mais de 90 países apoiaram-na.

Revista de Direito, Estado e Telecomunicações, v. 4, n. 1, p. 83-136 (2012)

DOI: https://doi.org/10.26512/1str.v4i1.21576
} 
Evolution (LTE) e Worldwide Interoperability for Microwave Access (Wimax), duas das quais haviam sido apontadas em 2007. ${ }^{50}$

Já se indicou que a Constituição da UIT atribui caráter vinculativo ao $\mathrm{RR}$, o que lhe dá força de tratado. Todavia, nunca houve a internalização orgânica desses documentos, ocorrendo isso de maneira pulverizada por meio das resoluções da Anatel que aprovam regulamentos sobre canalização e condições de uso de radiofrequências. É isso que tem ocorrido com o IMT.

As faixas de radiofrequência de $3 \mathrm{G}$ foram alocadas para a telefonia móvel, em obediência à decisão oriunda da UIT na CMR de 2000, por meio da Resolução da Anatel no 454, de 11 de dezembro de 2006, que aprovou o Regulamento sobre Condições de Uso de Radiofrequências nas Faixas de $800 \mathrm{MHz}, 900 \mathrm{MHz}, 1.800 \mathrm{MHz}, 1.900 \mathrm{MHz}$ e $2.100 \mathrm{MHz}$. A Resolução destinou essas radiofrequências ao SMP e o art. $1^{\circ}$ do Regulamento aprovado é explícito: "Este Regulamento tem por objetivo estabelecer as condições de uso das faixas de radiofreqüências constantes da Tabela 1 por sistemas digitais do SMP, em conformidade com o Regulamento de Radiocomunicações da UIT (S1.24)".

Embora a canalização realizada tenha prejudicado o uso de sistemas de acesso fixo sem fio para o STFC (Wireless Local Loop - WLL), exigindo sua desativação ou sua realocação no espectro ${ }^{51}$, e apesar de haver outras possibilidades de canalização possíveis e adotadas por outros países, a preliminar exposta na Consulta Pública $\mathrm{n}^{\circ}$ 724, de 10 de julho de 2006, denunciava a indisposição para com outras soluções: "Como resultado da presente Consulta Pública, a Anatel pretende: (...) XIII - adequar as condições de uso de radiofreqüências das faixas de $800 \mathrm{MHz}, 900 \mathrm{MHz}$, $1.800 \mathrm{MHz}$, e estabelecer as condições das novas faixas de $1.900 \mathrm{MHz}$ e

\footnotetext{
${ }^{50} \mathrm{~A}$ nota para a imprensa dessas conclusões encontra-se disponível em http://www.itu.int/net/pressoffice/press_releases/2010/40.aspx (último acesso em 25 de março 2011).

${ }^{51}$ As faixas do Wireless Local Loop (WLL) que acavalavam as faixas do IMT-2000 já haviam sido "congeladas" por meio das Resoluções da Anatel n 313 e n 314, de 19 de setembro de 2002, que restringiu a expedição de autorização de uso de radiofrequência e o licenciamento de novas estações para os sistemas de acesso fixo sem fio já em operação e definiu prazo para término da exclusividade da operação de faixas por esse sistema.
} 
2.100 MHz, para uso em aplicações que sigam as especificações IMT-2000, do UIT-R". ${ }^{52}$

Com a padronização do IMT-Advanced, a Agência expediu três resoluções que merecem destaque. A Resolução $\mathrm{n}^{\circ}$ 537, de 17 de fevereiro de 2010, publicou um novo Regulamento sobre Condições de Uso da Faixa de Radiofrequências de 3,5 GHz; a Resolução $n^{\circ}$ 544, de 11 de agosto de 2010 , modificou a destinação da faixa de 2,5 a $2,7 \mathrm{GHz}$; e a Resolução $\mathrm{n}^{\circ}$ 558, de 20 de dezembro de 2010, aprovou o Regulamento sobre Canalização e Condições de Uso de Radiofrequências na Faixa de $450 \mathrm{MHz}$ a $470 \mathrm{MHz}$. Os três regulamentos salientaram o fato de estarem sendo elaborados em conformidade ao RR, sobretudo aos sistemas móveis IMT.

Viu-se que os padrões 4G mais apropriados são o LTE e o Wimax. Este é um padrão novel, mas com arranjos comerciais mais pulverizados, baseados em royalty pools, ao passo que aquele é um padrão para redes móveis com um legado significativo, mas que, por outro lado, possui direitos comerciais mais concentrados. O desenvolvimento de tecnologia Wimax tem sido bastante incentivado no País, que também tem apoiado a sua padronização internacional para banda larga móvel, tendo conquistado sua indicação como interface 4G. O LTE não possui produção ou desenvolvimento nacional, sendo seus royalties detidos, em grande parte, por empresas estrangeiras, como a americana Qualcomm.

As faixas de $450 \mathrm{MHz}$ e de $2,5 \mathrm{GHz}$, no entanto, foram canalizadas, aparentemente, de forma a beneficiar a tecnologia de raiz CDMA (LTE) em vez de Wimax. Isso se verifica pelo fato de que a primeira foi canalizada à luz da Duplexação por Divisão de Frequência (FDD - Frequency Division Duplexing) e de que também o foi cerca de $70 \%$ da faixa de $2,5 \mathrm{GHz}$. Na faixa de $450 \mathrm{MHz}$, o uplink ficou na subfaixa de 451 a $458 \mathrm{MHz}$ e o downlink, na de 461 a $468 \mathrm{MHz}$; a faixa de $2,5 \mathrm{GHz}$ foi toda fatiada de maneira ótima para o FDD, com exceção de $50 \mathrm{MHz}(2.570$ a $2.620 \mathrm{MHz})$. A tecnologia Wimax faz uso de Duplexação por Divisão de Tempo (TDD -

\footnotetext{
${ }^{52} \mathrm{Na}$ Consulta Pública, previa-se que os sistemas WLL sairiam de operação em 2011. A melhor solução encontrada pela Agência, estampada no art. 24 do Regulamento, foi permitir que eles continuassem em operação, no entanto remanejados entre estações da mesma entidade.
}

Revista de Direito, Estado e Telecomunicações, v. 4, n. 1, p. 83-136 (2012)

DOI: https://doi.org/10.26512/lstr.v4i1.21576 
Time Division Multiplexing) e fica restrito, na faixa de $2,5 \mathrm{GHz}$, à subfaixa central apontada.

Faz sentido pensar que a faixa de $450 \mathrm{MHz}$ não foi destinada de forma ótima ao Wimax (TDD) porque ainda não há desenvolvimento concluído para a operação dessa tecnologia na faixa; a única tecnologia disponível é a CDMA. No entanto, o fato de a faixa de $2,5 \mathrm{GHz}$ ter sido pouco otimizada para o TDD não se harmoniza perfeitamente às iniciativas brasileiras de política produtiva e tecnológica. Pode-se ficar ainda mais estupefato quando se verifica que a forma de divisão da faixa de $2,5 \mathrm{GHz}$ foi puramente importada da Recomendação UIT-R M.1036, documento sem qualquer caráter vinculativo. ${ }^{53}$

Esse debate ficou explícito na Consulta Pública no 31, de 31 de julho de 2009, que precedeu a Resolução da Anatel $n^{\circ}$ 544/2010. Entre as contribuições, destaca-se a da Qualcomm: “A Qualcomm apoia o uso do espectro de $2.5 \mathrm{GHz}$ conforme estabelecido na opção $\mathrm{C} 1$ da recomendação UIT-R M.1036 (...)”. Houve, em contrapartida, uma séria de contribuições de advogados do padrão Wimax, alegando, entre outros argumentos, que a proposta violava a neutralidade tecnológica por impedir expressamente o uso de TDD em toda a faixa, que o uso de FDD em comunicações assimétricas implica um uso ineficiente do espectro e que a proposta beneficia desproporcionalmente as prestadoras de SMP e o padrão LTE. ${ }^{54}$

O caso do IMT ilustra bem como funciona a relação da Anatel com o RR e os documentos correlatos da UIT. Por um lado, as instituições republicanas existentes no âmbito da Agência têm-se mostrado capazes de servir de canal de expressão da sociedade, que contesta as propostas apresentadas pela Administração e recebe respostas em retorno. Por outro lado, existe um nítido caráter pétreo conferido ao $R R$ e às recomendações

\footnotetext{
${ }^{53}$ A primeira alternativa dada pela Recomendação para uso da faixa $(\mathrm{C} 1)$ foi a adotada pelo Brasil. Ressalte-se que a própria Recomendação admite a possibilidade de cada Estado compor o arranjo que lhe aprouver entre TDD e FDD dentro da faixa, mas destaca que, em caso de combinação, “(...) a separação duplex mostrada em C1 é preferível" (UIT 2007).

${ }^{54}$ Não foi possível acessar a resposta da Agência às contribuições, mas, a julgar pela permanência, no Regulamento, da canalização constante da Consulta Pública, pode se presumir que não houve adoção de outra forma diferente da prevista na Recomendação UIT-R M.1036.
} 
eventualmente levadas em consideração na formulação das propostas de ato normativo. Em outras palavras, admite-se que a proposta seja debatida em consulta pública, entretanto a Agência nitidamente não se dispõe a ir de encontro a algum ato da UIT, adotando-o como pressuposto do próprio procedimento de consulta. Isso ainda se associa à falta de coordenação com os setores governamentais que forjam as políticas industriais para o setor de TICs.

\subsubsection{A UIT e a Internet ${ }^{55}$}

A governança da Internet e posição da Corporação da Internet para Atribuição de Nomes e Números (Internet Corporation for Assigned Names and Numbers - ICANN) hoje no mundo se dá em um contexto de esvaziamento da UIT e de surgimento de estruturas paralelas, mais flexíveis e ágeis, porém menos universais, que passam a protagonizar temas de relevância global para o setor de TICs. A UIT, porém, vem tratando do tema Internet como pode, procurando exercer governança sobre ela até o limite de sua capacidade e proporcionando alguma coordenação dos países insatisfeitos com a ICANN.

Esses países alegam que a governança feita pela ICANN tem base informal e está adstrita, formalmente, à estrutura do governo americano, sob jurisdição daquele país. Isso dificulta a participação equânime de todos os países interessados, principalmente os países em desenvolvimento.

A governança da Internet demanda o envolvimento do direito internacional, em razão de sua natureza global descentralizada, e um sistema de freios e contrapesos entre distintas entidades de governança. Nas instituições domésticas, princípios de accountability e legitimidade são importantes na criação desses mecanismos. No contexto internacional, as arquiteturas podem se diferenciar consideravelmente por causa do envolvimento de múltiplas autoridades globais -, mas esses mesmos princípios são igualmente importantes. Portanto, podemos dizer que os órgãos de governança da Internet exigem um nível de legitimidade e accountability compatíveis com seus poderes decisórios. (...) Podemos inferir que a ICANN possui fortes poderes políticos e regulatórios, mas carece dos freios e contrapesos fundamentais que lhe

\footnotetext{
${ }^{55}$ Agradeço a Bruno Ramos pelos diálogos referentes a essa temática.
} 
provejam responsabilidade pública (accountability). ${ }^{56}$ (TRIPATHI, SINGH e DUBE 2009, 375-6)

A Cúpula Mundial sobre a Sociedade da Informação (World Summit on the Information Society - WSIS) e o Fórum de Governança na Internet (Internet Governance Forum - IGF) foram institucionalizados como meio de as Nações Unidas tentarem expandir sua esfera de governança sobre a Internet, competindo com a ICANN, que sempre se caracterizou como um órgão técnico. A própria UIT tem alçado voos sobre o assunto, não se conformando com sua posição de membro do Comitê Consultivo para Assuntos Governamentais (GAC - Governmental Advisory Committee) da ICANN.

O Setor da UIT encarregado da padronização de tecnologia e de aspectos de política pública para a Internet é o de Normalização (UIT-T). Esse Setor organiza seu trabalho por meio de vários grupos de estudo. A maior parte desses grupos lida com interoperabilidade técnica entre equipamentos e redes. O trabalho é majoritariamente conduzido pela iniciativa privada e, com as reformas aprovadas na Assembleia Mundial de Normalização de Telecomunicações de 2000, as normas consideradas puramente técnicas são aprovadas em seus próprios grupos de estudo, por meio de procedimentos mais rápidos. ${ }^{57}$ Para as recomendações que têm implicações políticas ou regulatórias, utiliza-se o procedimento de aprovação tradicional. (União Internacional de Telecomunicações 2005)

Os grupos de estudo que tratam de temas com forte impacto em políticas públicas e na atividade regulatória são os de $\mathrm{n}^{\circ} 2$ (Aspectos operacionais de

\footnotetext{
${ }^{56}$ Tradução livre do original: "IG demands the involvement of international law due to its global decentralized nature and a system of checks and balances among different governance entities. In domestic institutions, principles of accountability and legitimacy 21 are important in the creation of such mechanisms. In the international context, the designs may differ considerably - because of involvement of multiple global authorities - but these same principles are equally important. Thus, we can say that IG bodies require a level of legitimacy and accountability commensurate with their decision-making powers. (...) We can infer that ICANN is with full regulatory and political powers, but without the fundamental checks and balances that provided public accountability."

${ }^{57}$ Para a apresentação das demandas e das disputas que levaram à criação desse mecanismo, v. MACLEAN (2008).
} 
provimento de serviços e gerenciamento de telecomunicações) e o de $\mathrm{n}^{\mathrm{o}} 3$ (Princípios de tarifação e contabilidade, incluindo questões de políticas e de economia relacionadas às telecomunicações). $\mathrm{O}$ Grupo $\mathrm{n}^{\circ} 2$ lida, em sua maior parte, com recursos de numeração e de endereçamento e o Grupo $n^{\circ} 3$ tem como tema central harmonizar internacionalmente princípios a respeito da remuneração de interconexão de redes. Esses dois grupos trabalham com temas acerca da Internet que se sobrepõem, de alguma forma, às atribuições da ICANN.

Um desses temas está refletido na Recomendação UIT-T D.50, a respeito da remuneração do tráfego de Internet. O documento é bastante lacônico e recomenda que os Estados garantam, nacionalmente, que os provedores de conectividade Internet internacional façam acordos bilaterais para prover o serviço aos interessados. Ainda aponta que eventuais pagamentos pela aquisição desse serviço sejam feitos mediante os acordos bilaterais. (União Internacional de Telecomunicações 2008) Muitos países, sobretudo os em desenvolvimento, vêm tentando promover mudanças no texto dessa Recomendação, alegando que ela solidifica as desigualdades mundiais ao invés de aproximar países ricos e pobres, respectivamente, com alto volume de tráfego e com baixo volume de tráfego.

O Regulamento das Telecomunicações Internacionais (RTI) é a norma da UIT que instituiu o sistema de remuneração de tráfego internacional e, juntamente com algumas recomendações, propiciou o subsídio de países mais pobres pelas chamadas originadas dos países mais ricos. Em outras palavras, recebia-se a tarifa internacional quando a rede local era usada para terminar o tráfego oriundo de outro país. Como os países em desenvolvimento sempre receberam mais chamadas do que realizaram, eram beneficiados com esse sistema. Com a liberalização do setor de telecomunicações em vários países, o RTI tem caído em desuso.

Talvez a perversidade mais visível da ausência de regulação sobre a remuneração de redes internacionais, atualmente, seja o tráfego sob o protocolo Internet (IP - Internet Protocol). Com a Recomendação UIT-T D.50 - praticamente uma não regulação -, pode-se dizer que os países menores, mais pobres, menos dotados de infraestrutura e mais isolados estão, de alguma forma, subsidiando as redes dos países maiores, mais ricos, mais centrais e mais dotados de infraestrutura. 
Para a troca de tráfego IP, existem duas modalidades: o peering e o trânsito. O peering ocorre quando duas operadoras com tamanho razoável (em termos de número de usuários e de volume de tráfego gerado) decidem interconectar suas redes diretamente e não cobram remuneração pelo tráfego entrante ou sainte de uma para a outra. O trânsito ocorre, geralmente, quando uma operadora menor precisa adquirir interconexão ao backbone Internet, mas, como acessa mais o conteúdo de outras redes do que recebe conexões, precisa adquirir certo volume de banda de outra operadora maior, que não tem incentivo comercial a entrar em uma relação paritária de repartição de custos - o peering. Portanto, segundo avaliação da UIT, os pequenos operadores - sobretudo os localizados nos países menores e mais periféricos - terminam por ser prejudicados ao ter de adquirir capacidade de banda de tráfego, custeando-o totalmente, para obter acesso à Internet. (Are poor countries subsidizing the rich? 2005 $)^{58}$

Esse sistema, que amplia as disparidades econômicas entre ricos e pobres e entre grandes e pequenos, reproduz-se no Brasil. Tão abreviado quanto a Recomendação UIT-T D.50 é o Regulamento Geral de Interconexão (RGI), aprovado pela Resolução da Anatel $n^{\circ} 410$, de 11 de julho de 2005, ao tratar da Internet. O mesmo ambiente de livre negociação previsto na Recomendação da UIT é transposto para o RGI, conforme se observa a partir do art. 25:

Art. 25. As prestadoras podem, nos termos da regulamentação, realizar Interconexão de suas redes para cursar tráfego, originado e terminado em suas redes.

$\S 1^{\circ}$. É vedada a Interconexão de redes com propósito diferente de cursar tráfego entre Usuários das redes interconectadas.

$\S 2^{\circ}$. A ligação de Redes de Telecomunicações de suporte a backbone Internet é considerada Interconexão classe V.

Como resultado, tem-se que as disparidades de mercado entre, de um lado, proprietárias de grandes backbones e de saídas internacionais para a

\footnotetext{
${ }^{58}$ As tentativas de alteração dessa Recomendação estão sendo infrutíferas e, politicamente, vem havendo um movimento de revigorar o RTI, para dar conta do tema da remuneração do tráfego IP e instituir a obrigação de realização de peering ou, ao menos, conformar um sistema de remuneração menos assimétrico que o trânsito atual.
} 
Internet e, de outro, pequenos provedores de acesso à Internet mantêm-se. O custo do trânsito IP, funcionando como instrumento de exercício do poder de mercado, e a imobilidade da atividade regulatória a esse respeito, reproduzindo a sistemática internacional, provocou o CGI.br a instituir o seu programa de Pontos de Troca de Tráfego (PTTs) ${ }^{59}$ e, de certa forma, colaborou até mesmo para que o Poder Executivo restaurasse a Telecomunicações Brasileiras S.A. - Telebrás, por meio do Decreto $\mathrm{n}^{\circ}$ 7.175 , de 12 de maio de 2010, com o propósito de reduzir o preço desse insumo no atacado e propiciar maior competição e menores custos para o usuário final.

Embora seja um tema à disposição do regulador nacional, nunca foi posto pública e amplamente em discussão no âmbito da Agência. $\mathrm{O}$ assunto foi tratado por meio da Consulta Pública $n^{\circ} 549$, de 13 de julho de 2004, porém a única contribuição referente à imposição de maior obrigatoriedade na Interconexão Classe $\mathrm{V}$ foi rechaçada sob o argumento de que a facultatividade preservaria, de maneira mais adequada, o princípio do uso eficiente das redes. A Agência também não publicou posteriormente quaisquer regras específicas para remuneração de tráfego entre redes de dados ou de tráfego IP. Com isso, o Brasil defende internacionalmente uma maior transparência na atividade de governança da Internet ${ }^{60}$ e a modificação do sistema de troca de tráfego, mas, aparentemente, condiciona a mudança desse sistema, em âmbito interno, à evolução dessa discussão no plano internacional.

\section{Conclusão}

Inexiste alternativa para a internalização das normas e das pseudonormas internacionais, à luz do republicanismo, que não passe por procedimentos de

\footnotetext{
${ }^{59}$ Para mais informações acerca dessa iniciativa, v. MOREIRAS e GETSCHKO (2008).

${ }^{60}$ Vide, por exemplo, relatório de viagem da delegação brasileira à Reunião Conjunta dos dois Grupos Relatores sobre Interconexão Internacional Internet, Custos e de Metodologia de Fluxo de Tráfego, ocorrida em Bruxelas, em outubro de 2003, disponível http://www.anatel.gov.br/Portal/exibirPortalRedireciona.do?codigoDocumento=9152 8 (último acesso em 27 de março de 2011).
}

Revista de Direito, Estado e Telecomunicações, v. 4, n. 1, p. 83-136 (2012)

DOI: https://doi.org/10.26512/lstr.v4i1.21576 
democracia participativa, contestatória ou deliberativa. Um conjunto de instituições dessa natureza foi criado no âmbito da introdução das agências reguladoras no País. É possível concluir, por um lado, que, em geral, elas têm se prestado aos objetivos para os quais existem, quais sejam, os de serem canais de participação republicana no contexto de uma hipertrofia histórica do Poder Executivo em dados setores da economia e o de informarem a Administração Pública acerca da melhor alternativa em prol do bem comum. As instituições participativas no âmbito da Anatel, por outro lado, ainda não atuam de forma plenamente republicana como caminhos para a legitimação das políticas internalizadas em razão de normas e pseudonormas internacionais.

No setor de telecomunicações, não existe um caminho específico para a internalização das decisões emitidas pela UIT que constituam normas ou pseudonormas. A transposição de recomendações e regulamentos para o direito interno sói ocorrer embutida em resoluções da própria Agência. $\mathrm{Na}$ medida em que todas as resoluções submetem-se a processos de participação da sociedade, as decisões internacionais passam, materialmente, pelo crivo contestatório neorrepublicano. Apesar disso, os documentos com efeito vinculativo são nitidamente vistos como incontestáveis, na medida em que a eles se atribui força de tratado. Esquece-se, porém, que até os tratados, depois de já firmados, são contestados à luz dos interesses nacionais mediante processos republicanos antes de serem internalizados.

Um ponto em que a internalização das normas e das pseudonormas internacionais pela Anatel é nitidamente republicano é o debate existente previamente à formação da posição a ser apresentada pelo País em foros internacionais. As CBCs são os espaços em que isso ocorre. Elas trabalham permanentemente sobre os documentos preparatórios das conferências mundiais dos setores da UIT e de outros organismos internacionais de relevância para o setor e, muitas vezes com a participação da academia e da iniciativa privada, ajustam os pontos e os argumentos a serem defendidos pelo País no espaço institucional global. Todavia, pode-se reconhecer a fraca institucionalidade desses órgãos em serem a porta universal do País para esses eventos.

As CBCs possuem dificuldades práticas em incentivar a participação da sociedade civil, em coordenar seus trabalhos internamente à Agência e em articular uma posição universal do País para os temas submetidos a decisões 
em nível internacional. É verificável a participação de algumas entidades não estatais nas discussões, porém organizações da sociedade civil de maneira geral e, particularmente, representações dos usuários praticamente não tomam parte nos trabalhos de formação da posição do País. Não é raro também, a Agência adotar uma posição no ambiente internacional e não agir de forma coerente no ambiente nacional. Além disso, outros órgãos do governo - ministérios e autarquias, por exemplo - não costumam fomentar esses espaços de discussão como polos de formação da posição do Brasil em temas que lhes tanjam; o próprio Ministério das Relações Exteriores não acompanha regularmente as reuniões das $\mathrm{CBCs}$. O resultado desse cenário é a esterilidade das posições afinal formadas. Ainda que a Agência empenhese a conformar a melhor posição possível, a falta de insumos participativos e de pontos de vista extrassetoriais logicamente empobrece e enfraquece a legitimidade das decisões do País no plano internacional.

Todas essas dificuldades para fortalecer um mecanismo de participação prévia às decisões internacionais contribuem para reforçar a falta de confiabilidade atribuída às normas e às pseudonormas internacionais. Muitos autores tentam trabalhar o paradigma republicano em nível internacional, procurando enxergar uma comunidade global e uma arena pública inclusiva simbolizada pelas OIs, mormente as do Sistema ONU. Nesse contexto, a sociedade civil global organizada - principalmente organizações não governamentais com atuação internacional - é observada por boa parte da doutrina como garantidora da observância de um bem comum global nas decisões de OIs e de outros organismos internacionais, na medida em que minimamente participativos.

Viram-se os perigos de se confiar de maneira absoluta na participação supostamente democrática dos organismos internacionais. Em geral, os organismos deliberativos internacionais carecem de representatividade, de um sistema de freios e contrapesos eficaz, de submissão a alguma jurisdição reconhecida como legítima por todos, de instituições contestatórias que estimulem a participação neorrepublicana, de um ambiente organizado, de transparência e de responsabilidade pública (accountability).

Muitas OIs hoje gozam de uma independência relativa aos Estados que as criaram, desafiando a filosofia jurídica internacional, que ainda se apoia largamente na concepção westfaliana. O Estado nacional deve ter, portanto, formas jurídicas minimamente coerentes no relacionamento com esses 
organismos e suas decisões. O Brasil, por exemplo, é dotado de um complexo sistema para internalização de tratados, garantindo que a sociedade, por meio do Congresso Nacional, manifeste-se contra ou a favor. Instituir um processo similar para a internalização das normas e das pseudonormas emitidas pelas OIs é uma exigência das instituições republicanas que conduzem o Estado desde o seu nascimento e que estão na base da Constituição moderna.

\section{Bibliografia}

AGUILLAR, Fernando Herren. Direito econômico e globalização. In: Direito global, por Carlos Ari SUNDFELD e Oscar Vilhena VIEIRA, 269-78. São Paulo: Max Limonad, 1999.

AMAN JR., Alfred C. Globalization, democracy, and the need for a new Administrative Law. In: UCLA Law Review, 2002: 1687-716.

ARAGÃO, Alexandre Santos de. $O$ poder normativo das agências reguladoras independentes e o Estado Democrático de Direito. In: Revista de Informação Legislativa, outubro/dezembro de 2000: 275-99.

A $\beta$ MANN, Eberhard Schmidt. The internationalization of administrative relations as a challenge for Administrative Law scholarship. In: German Law Review, 2008: 2061-79.

BELLAMY, Richard. Republicanism, democracy, and constitutionalism. In:

Republicanism and Political Theory, por Cécile LABORDE e John MAYNOR, 159-89. Malden: Blackwell Publishing, 2008.

BINENBOJM, Gustavo. Monismo e dualismo no Brasil: uma dicotomia afinal irrelevante. In: Revista Forense, abril/maio/junho de 2000: 39-48.

BRASIL. Ministério das Comunicações. Caderno da $1^{a}$ Confecom (Conferência Nacional de Comunicação). Brasília: Secretaria de Comunicação Social da Presidência da República, 2010.

BURKE, Peter. A Revolução Francesa da Historiografia: a Escola dos Annales (1929-1989). São Paulo: Unesp, 2003.

CAMPILONGO, Celso Fernandes. Teoria do direito e globalização econômica. In: Direito global, por Carlos Ari SUNDFELD e Oscar Vilhena VIEIRA, 77-92. São Paulo: Max Limonad, 1999.

CASSESE, Sabino. Administrative Law without the State? The challenge of global regulation. In: International Law and Politics, 2005: 663-94. 
CHARNOVITZ, Steve. The emergence of democratic participation in global governance (Paris, 1919). In: Indiana Journal of Global Legal Studies, inverno de 2003: 45-77.

COLLINS, Katherine. International accounting rate reform: the role of international organizations and implications for developing countries. In: Law \& Policy in International Business, 2000: 1077-92.

COWHEY, Peter F. The international telecommunications regime: the political roots of regimes for high technology. In: International Organization, primavera de 1990: 169-99.

DELBRÜCK, Jost. Exercising public authority beyond the state: transnational democracy and/or alternative legitimation strategies? In: Indiana Journal of Global Legal Studies, inverno de 2003: 29-43.

DIVER, Colin S. Policymaking paradigms in Administrative Law. In: Harvard Law Review, dezembro de 1981: 393-434.

GUERMAZI, Boutheina. The GATS agreement on basic telecommunications: a developing country perspective. In: Governing global electronic networks: international perspectives on policy and power, por William J. DRAKE e Ernest J. WILSON III, 187-230. Cambridge: The MIT Press, 2008.

JAYAKAR, Krishna. Globalization and the legitimacy of international telecommunications standard-setting organizations. In: Indiana Journal of Global Legal Studies, 1998: 711-38.

KELLEY, Thomas. Beyond the Washington Consensus and New Institutionalism: What is the Future of Law and Development? In: North Carolina Journal of International Law and Commercial Regulation, 2010: 539-54.

KINNEY, Eleanor D. The emerging field of International Administrative Law: its content and potential. In: Administrative Law Review, 2002: 41534.

LAENDER, Gabriel Boavista. A separação de poderes e o processo de institucionalização das agências reguladoras de telecomunicações nos EUA e no Brasil. Brasília: Faculdade de Direito, Universidade de Brasília - Dissertação (Mestrado em Direito), 2009.

LIMA, Venício A. de. Coronelismo eletrônico na radiodifusão educativa. In: Observatório da Imprensa. 12 de junho de 2007. 
http://www.observatoriodaimprensa.com.br/artigos.asp?cod=437IPB002 (acesso em 15 de março de 2011).

LUNEBURG, William V. Civic republicanism, the First Ammendment, and Executive branch policymaking. In: Administrative Law Review, verão de 1991: 367-410.

MACLEAN, Don. Sovereign right and the dynamics of power in the ITU: lessons in the quest for inclusive global governance. In: Governing global electronic networks: international perspectives on policy and power, por William J. DRAKE e Ernest J. WILSON III, 83-126. Cambridge: The MIT Press, 2008.

MACLEAN, Don, David SOUTER, James DEANE, e Sarah LILLEY. Louder voices: strengthening developing country participation in international ICT decision-making. Londres: Commonwealth Telecommunications Organisation/Panos London, 2002.

MAYNOR, John W. Modern republican democratic contestation. In: Republicanism in theory and practice, por Iseult HONOHAN e Jeremy JENNINGS, 125-38. Oxfordshire: Routledge, 2006.

—. Republicanism in the modern world. Cambridge: Polity Press, 2003.

MEDEIROS, Gierck Guimarães. Origem das agências reguladoras no Brasil. In: Direito das telecomunicações: estrutura institucional regulatória e infra-estrutura das telecomunicações no Brasil, Márcio Iorio Aranha (org.), 29-79. Brasília: Universidade de Brasília, 2005.

MORAVCSIK, Andrew. Is there a 'democratic deficit' in world politics? A framework for analysis. In: Government and Opposition, abril de 2004: 336-63.

MOREIRAS, Antonio M., e Demi GETSCHKO. Os Pontos de Troca de Tráfego, o PTTMetro e a Internet brasileira. Centro de Estudos e Pesquisas em Tecnologia de Redes e Operações. 25 de outubro de 2008. http://www.ceptro.br/pub/CEPTRO/PalestrasPublicacoes/PTT-

semanatec.pdf (acesso em 27 de março de 2011).

PEREIRA, Luiz Carlos Bresser. Construindo o Estado republicano: democracia e reforma da gestão pública. Rio de Janeiro: Editora FGV, 2009.

PETTIT, Philip. Republicanism: a theory of freedom and government. Oxford: Oxford University Press, 1997. 
PRATA, José, Nirlando BEIRÃO, e Teiji TOMIOKA. Sérgio Motta: o trator em ação. São Paulo: Geração Editorial, 1999.

REZEK, Francisco. Direito internacional público. $10^{a}$ ed., São Paulo: Saraiva, 2005.

SCHEUERMAN, William E. Is republican regulatory law the answer to globalization? In: University of Toronto Law Journal, 2002: 301-11.

SCHWARZMANTEL, John. Republican theory and democratic transformation. In: Republicanism in theory and practice, por Iseult HONOHAN e Jeremy JENNINGS, 140-53. Oxfordshire: Routledge, 2006. SEIDENFELD, Mark. A civic republican justification for the bureaucratic State. In: Harvard Law Review, 1992: 1511-76.

SOUTER, David. "Louder Voices" and the international debate on developing country participation in ICT decision making. In: Governing global electronic networks: international perspectives on policy and power, por William J. DRAKE e Ernest J. WILSON III, 429-62. Cambridge: The MIT Press, 2008.

SOUTO, Marcos Juruena Villela. Direito administrativo regulatório. $2^{\mathrm{a}}$ ed. Rio de Janeiro: Lumen Juris, 2005.

SUNDFELD, Carlos Ari. A Administração Pública na era do direito global. In: Direito global, por Carlos Ari SUNDFELD e Oscar Vilhena VIEIRA, 157-68. São Paulo: Max Limonad, 1999.

SUNDFELD, Carlos Ari. Introdução às agências reguladoras. In: Direito administrativo econômico, por Carlos Ari SUNDFELD, 17-38. São Paulo: Malheiros, 2006.

SUNDFELD, Carlos Ari. Processo e procedimento administrativo no Brasil. In: As leis de processo administrativo, por Carlos Ari SUNDFELD e Guillermo Andrés MUÑOZ, 17-36. São Paulo: Malheiros, 2006.

SUNSTEIN, Cass. Beyond the Republican Revival. In: Yale Law Journal, 1987-1988: 1539-90.

TCHIKAYA, Blaise. Le droit international des télécommunications. Paris: Presses Universitaires de France, 1998.

TRIPATHI, Surya Mani, Anshu Pratap SINGH, e Dipa DUBE. Internet governance: a developing nation's call for administrative legal reform. In: International Journal of Legal Information, 2009: 368-84. 
União Internacional de Telecomunicações. Are poor countries subsidizing the rich? International Telecommunications Union. 2005. http://www.itu.int/itunews/manager/display.asp?lang=en\&year=2005\&iss $\underline{\text { ue}=03 \& i p a g e}=$ interconnectiv-poor\& (acesso em 27 de março de 2011).

IMT-2000 project: what is IMT-2000. Internacional Telecommunications Union. 2001-2002. http://www.itu.int/osg/imtproject/docs/What_is_IMT2000-2.pdf (acesso em 25 de março de 2011). ITU's History. 10 de fevereiro de 2010. http://www.itu.int/en/history/overview/Pages/history.aspx (acesso em $1^{\circ}$ de março de 2011). . ITU-T guide for beginners. $2^{\mathrm{a}}$ ed. Genebra, 2005. . Recomendação UIT-T D.50. Genebra, 2008.

. Setor de Radiocomunicações. CPM Report on technical, operational and regulatory/procedural matters to be considered by the 2007 World Radiocommunication Conference. Documento preparatório para a Conferência Mundial de Radiocomunicação, Genebra, 2007.

- Setor de Radiocomunicações. Final acts of the World Radiocommunication Conference (WRC-07). Relatório final da Conferência Mundial de Radiocomunicação de 2007, Genebra, 2008. . Recomendação UIT-R M.1036-3. Genebra, 2007

VIEIRA, Oscar Vilhena. Realinhamento constitucional. In: Direito global, por Carlos Ari SUNDFELD e Oscar Vilhena VIEIRA, 15-48. São Paulo: Max Limonad, 1999.

WOODWARD, Barbara K. Global civil society and International Law in global governance: some contemporary issues. In: International Community Law Review, 2006: 247-355.

ZICCARDI, Piero. Evolução e perspectivas da escola italiana de direito internacional no século XX. In: Estudos jurídicos e políticos, dezembro de 2005: 203-27. 
